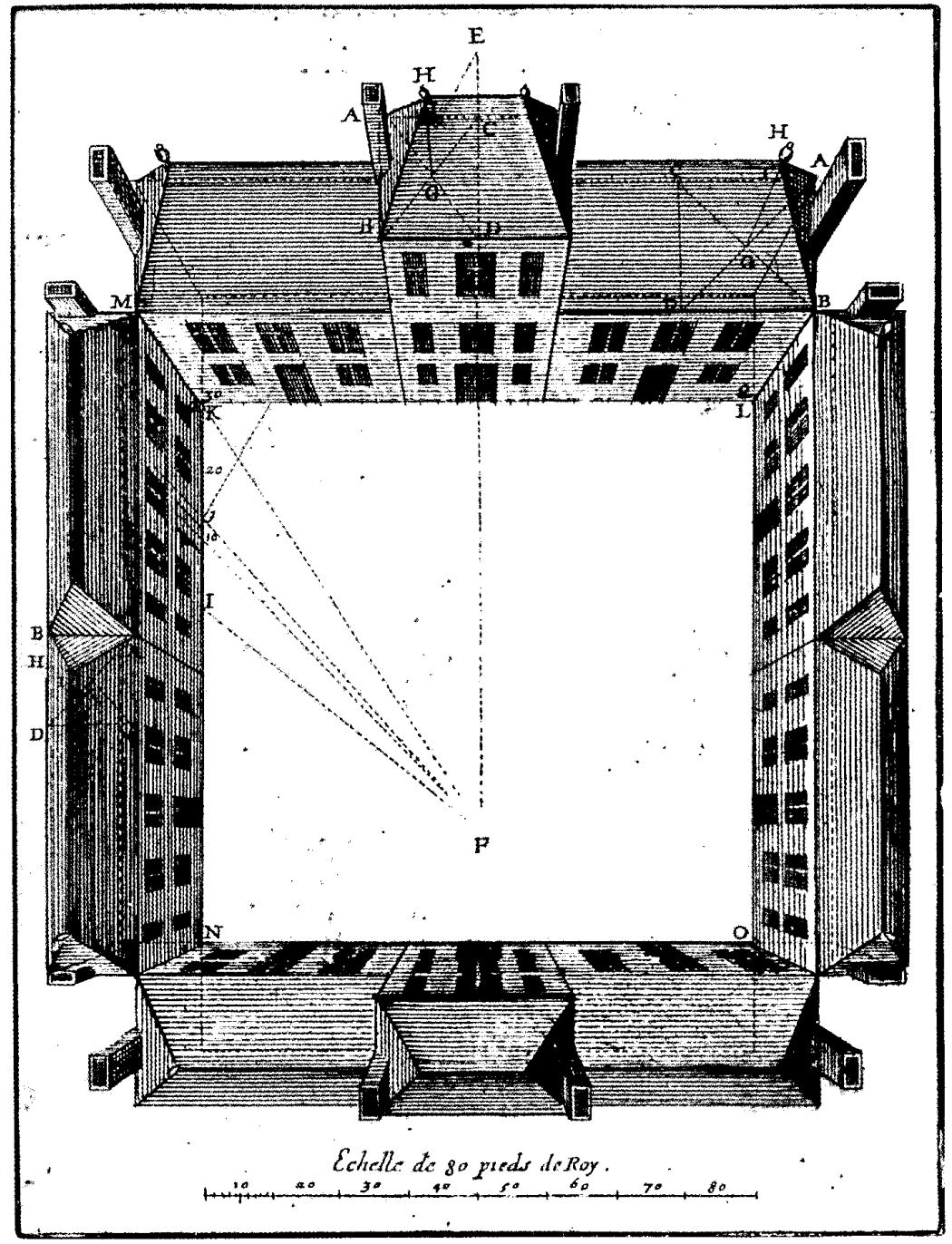




\section{María M. Bjerg}

Doctora en Historia, profesora adjunta de Historia Social General en el Departamento de Ciencias Sociales de la Universidad Nacional de Quilmes e investigadora adjunta del Consejo Nacional de Investigaciones Científicas y Técnicas (Buenos Aires). Ha publicado el libro Entre Sofie y Tovelille. Una bistoria de la inmigración danesa en la Argentina, 1848-1930, Biblos, Buenos Aires, 2001, que es una versión revisada de su tesis de doctorado. Sus artículos han aparecido en revistas científicas de Argentina, Suecia, Italia, España y Estados Unidos. Se encuentra preparando un libro sobre la vida cotidiana en un pueblo de la frontera en la provincia de Buenos Aires en el siglo XIX.

\section{Resumen}

El artículo intenta reconstruir la vida cotidiana de los vecinos de un pueblo de la frontera de la provincia de Buenos Aires, en un tiempo (la segunda mitad del siglo XIX) signado por las amenazas de molones e invasiones indígenas. Para reconstruir la experiencia de ese mundo local se utiliza una estrategia narrativa que repara en los acontecimientos y los protagonistas de una densa sociabilidad empleando una amplia gama de fuentes de las cuales la más relevante es el diario personal de Dorothea Fugl, una inmigrante danesa que vivió en Tandil durante aquellos años.

\section{Palabras clave:}

Argentina, siglo XIX, historia social, vida cotidiana, frontera, malones, sociabilidad local.

\section{Abstract}

This article attempts to reconstruct the everyday life of the residents of a border town in the province of Buenos Aires at a time (the second half of the $19^{\text {th }}$ century) marked by the threat of Indian raids and invasions. In order to reconstruct the experience of this local world, the author employs a narrative strategy that focuses on the events and protagonists of a dense society, using a wide range of sources, the most important of which is the personal diary of Dorothea Fugl, a Danish immigrant who lived in Tandil during this period.

Key words:

Argentina, $19^{\text {th }}$ century, social history, everyday life, frontier, Indian raids, local society.

Fecha de recepción: agosto de 2002

Fecha de aceptación: diciembre de 2002 


\title{
Un eco del desierto. El ocaso de la sociedad de frontera en un pueblo de la campaña. Tandil, 1855-1875*
}

\author{
María M. Bjerg
}

$A$ fines del verano de 1860 , tras un largo viaje por mar y una agobiante travesía en diligencia por la pampa, Dorothea Fugl llegaba a Tandil. El 25 de junio de 1859 , esta joven danesa que acababa de cumplir 20 años se había casado en Lolland, una isla del sur de Dinamarca, con su tío, Juan Fugl, un hombre casi tres décadas mayor que ella que vivía en Argentina desde 1844 y en Tandil desde 1848. Desafiando las normas del mundo campesino en el que se había criado y el mandato de su familia que esperaba que se casase con un aldeano y permaneciera en Lolland velando por la vejez de sus padres, dos semanas después de la boda Dorothea abandonó los recortados contornos de la isla para seguir a su marido que, después de una prolongada visita a Dinamarca, debía regresar a su chacra en el sur de la provincia de Buenos Aires. ${ }^{1}$

Dorothea vivió quince años en Tandil, un tiempo al que calificó como el más intenso de su vida. En 1872, después de

* Agradezco los comentarios de Raúl Mandrini, Judich Farberman, Silvia Ratto, Marcelino Iriani, Carlos Paz, y de los árbitros anónimos de esta revista.

${ }^{1}$ Sobre la vida de Juan Fugl véase Fugl, Memorias, 1989, y Bjerg, Sofie, 2001. doce años de ausencia, los Fugl visitaron Dinamarca. En aquella visita, que se prolongó casi catorce meses, dos de los tres hijos que habían tenido en Argentina murieron víctimas de una epidemia de difteria que asolaba a la isla de Lolland. En el viaje hacia Dinamarca Dorothea había quedado embarazada, y aquel año "de perplejidad y dolor" nació una niña en cuya compañía emprendieron el retorno a Tandil, dejando atrás al mayor de los hijos, que quedaba pupilo en una escuela de Copenhague. De vuelta en su hogar, presa de la tristeza, Dorothea no pudo sobrellevar el dolor de la muerte y el temor a no volver a ver a su hijo. Su esposo decidió vender sus propiedades y marcharse de Argentina. En abril de 1875, Dorothea cerraba el ciclo de su vida en la frontera.

Los años que esta inmigrante danesa vivió en Tandil también fueron un tiempo intenso para Argentina, una sociedad que transitaba entre dos países: el país criollo y el país aluvial. ${ }^{2}$ El formidable crecimiento económico, la abrumadora pre-

${ }^{2}$ Esta es la expresión que el historiador José Luis Romero utilizó para caracterizar a la sociedad argentina que emergió de la inmigración masiva de las últimas décadas del siglo XIX. 
sencia de inmigrantes europeos, el fin de las luchas facciosas que habían jalonado el largo camino de la organización del Estado y la incorporación del desierto con la campaña militar emprendida a mediados de $1878,{ }^{3}$ configuraron un país distinto. Sin embargo, en la trama que subyace a la transición más que discontinuidad se advierte una compleja relación entre viejas prácticas y novedades que sugiere que el país aluvial nacía del seno de la sociedad criolla. ${ }^{4}$

Este trabajo intenta recrear la forma en que los vecinos de Tandil vivieron aquel tiempo de tránsito. Nacido en abril de 1823 como un destacamento de frontera al que su fundador, el gobernador Martín Rodríguez, bautizó "fuerte Independencia", en sus orígenes fue un eslabón más de una cadena de fortines creados para proteger las tierras ganaderas de la provincia de Buenos Aires al sur del río Salado (véase mapa) de las incursiones de los habitantes del desierto. En las décadas de 1860 y 1870 , el alejamiento de la línea militar que separaba los dominios blancos e indígenas, y los cambios en la vida material y en el paisaje social, auguraban el ocaso del mundo de la frontera, de cuyas necesidades Tandil había emergido. Aquellas serían, sin embargo, unas décadas todavía enhebradas en la trama de un pasado sostenido en el frágil equi-

\footnotetext{
${ }^{3}$ Se refiere a la campaña militar que incorporó vastos territorios de la Argentina que estaban bajo el control de distintas parcialidades indígenas. Cuando hablamos de "desierto" estamos utilizando el lenguaje con el que los contemporáneos se referían a las tierras controladas por los indios.

${ }^{4}$ Sobre el problema de las continuidades y rupturas entre ambas sociedades véase Anuario IEHS, núm. 12, 1992, Tandil, sección I, pp. 13-173.
}

libro de las relaciones entre cristianos e indios. Expresada en la memoria del malón que asoló a Tandil en 1855 y en las recurrentes amenazas de una nueva invasión indígena, esa fragilidad era el telón de fondo sobre el que transcurría la vida de la familia Fugl y de sus vecinos del pueblo.

Para reconstruir la experiencia de ese mundo en transición utilizaremos una estrategia narrativa que repara en los acontecimientos y los protagonistas de una densa sociabilidad local y que suma a las fuentes más tradicionalmente trabajadas por los historiadores del periodo ${ }^{5}$ dos testimonios poco usuales para un contexto como el de la campaña de Buenos Aires en el siglo XIX: ${ }^{6}$ el diario de Dorothea Fugl y las memorias de su esposo. El primero fue escrito entre el día de su casamiento en la isla de Lolland y el retorno definitivo de la familia a Dinamarca, en tanto que las segundas son el producto de los recuerdos de Juan durante los años finales de su vida en Copenhague, ${ }^{7}$ y evocan su experiencia en Argentina. Ambas fuentes nos abren una ventana desde la cual observar a la sociedad de un pueblo de la campaña de la provincia de Buenos Aires en las décadas finales del sinuoso camino que en la segunda mitad del siglo XIX condujo a la organización nacional. ${ }^{8}$

S Entre las fuentes más trabajadas se cuentan los archivos de justicia de Paz, los censos y los testamentos.

${ }^{6}$ En otros contextos, como en el mundo rural del Medio Oeste de Estados Unidos o en la pradera canadiense, los diarios y las memorias son fuentes difundidas y de fácil acceso que además han sido ampliamente utilizadas por los historiadores.

${ }^{7}$ Fugl, Memorias, 1989.

${ }^{8}$ Nos referimos al periodo $1852-1880$, desde la batalla de Caseros que terminó con el poder político 


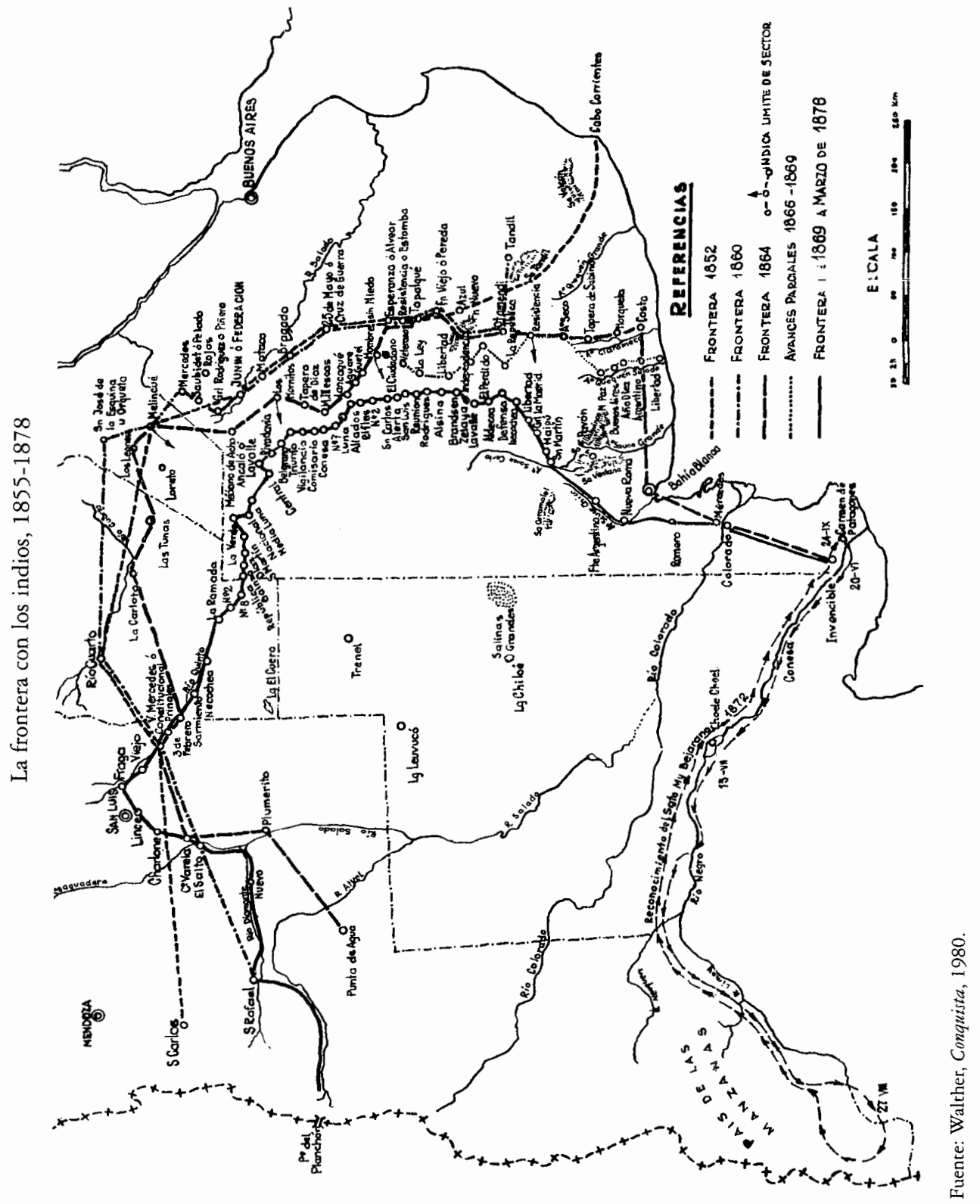


Sin embargo, el abanico de temas que despliega el diario de Dorothea es mucho más rico que el que nos ofrece su esposo en su reconstrucción autobiográfica. Esta mujer nos revela sus nociones sobre el amor conyugal, la maternidad, los hijos y la rutina doméstica, al tiempo que se expresa sobre el mundo que la rodeaba. La vida material, las prácticas sexuales y las formas familiares de una campaña donde escaseaban las mujeres y no faltaban los hijos bastardos, ${ }^{9}$ sus vecinos, sus amigas criollas, la sociabilidad del pueblo, el impacto del devenir político nacional sobre esa pequeña comunidad rural y las relaciones entre salvajes y cristianos, configuran el montaje textual del diario, cuya selec-

de Juan Manuel de Rosas y puso en cuestión el predominio de Buenos Aires sobre el resto de las provincias, hasta la asunción de Julio A. Roca a la presidencia de Argentina, un hito que marca la consagración del imperio de la nación sobre el de las provincias. Esta época estuvo signada por luchas facciosas y antagonismos que, por ejemplo, gestaron durante casi diez años una estructura de poder bifronte: la Confederación que incluía a trece provincias nucleadas en torno a la Constitución Nacional sancionada en 1853 , y el Estado de Buenos Aires. El enfrentamiento y la conflictividad entre estas dos órbitas de poder en las que se dividió el país llevaron a dos enfrentamientos bélicos, las batallas de Cepeda en 1859 y Pavón en 1861. El triunfo de las fuerzas de Buenos Aires en la última terminó con la separación, dando comienzo a una nueva etapa en la que a pesar de rebeliones internas, asesinatos y desconocimiento de la autoridad, se iniciaba un largo camino en el que, en un contexto político impregnado por el liberalismo, se construiría la organización constitucional definitiva del país. Sobre este periodo véanse los trabajos clásicos de Gorostegui de Torres, Argentina, 1969; Ozslak, Formación, 1982, y el más reciente de Bonaudo, Liberalismo, 1999.

${ }^{9}$ Bjerg, "Imágenes", 2001, pp. 8-19. ción y jerarquización de temas responde tanto al estado de ánimo de su autora -que pasa con mucha facilidad de la efusión a la melancolía- como a la lógica de un contexto que atraviesa, como veremos más adelante, por una época de tensa calma e inestable equilibrio.

Vale la pena aclarar al lector que, a pesar de su riqueza, el diario no es uniforme ni en la elección de los temas ni en la atención que su autora le ofrece a los mismos. Mientras la familia, las relaciones sociales entre las mujeres de la campaña o la organización del dominio doméstico son objeto de las narraciones más densas, otros tópicos, como el de la vida pública o la forma en que los vecinos de Tandil atravesaron por el convulsionado tiempo de transición del que hablábamos antes, son abordados de manera más esporádica. Empero, la opción de incluir a Dorothea como una de las protagonistas de nuestro relato (protagonista que por momentos permanece silenciosa mientras las voces de otros vecinos dominan la escena) obedece al paralelismo que su vida (y la de su esposo) en Tandil guarda con el ocaso de la sociedad de frontera, un tiempo en el que los indios seguían constituyendo una amenaza para los pueblos de la campaña sur de Buenos Aires (tópico sobre el que nos detendremos largamente en este trabajo). Es claro que ese paralelismo también fue el de otros vecinos contemporáneos de la familia Fugl que, sin embargo, no dejaron rastros de su experiencia, o, si lo hicieron, los mismos no tienen continuidad a lo largo del periodo que nos ocupa. De esta suerte, relatos como los de Dorothea y Juan son poco frecuentes en el panorama documental de la sociedad de frontera. Si bien existen fuentes que nos hablan de aquel mundo en el 
siglo XIX, en particular la literatura de viajeros, ${ }^{10}$ se trata de testimonios de naturaleza diferente. Aunque los Fugl suelen adoptar el tono de las narrativas de viaje -en particular en el uso de algunas expresiones que los hacen parte de una retórica eurocentrada propia de los viajeros-, no debemos perder de vista que ambos pasaron una parte importante de sus vidas en Tandil, y que se integraron al vecindario del pueblo adaptándose y adoptando los códigos y significados de aquella sociedad.

Antes de entrar al tema que nos ocu$\mathrm{pa}$, nos parece pertinente hacer una breve digresión sobre las formas en que ha sido abordado en las últimas décadas el tema de la frontera pampeana. Desde una mirada que no lograba integrar a los mundos que esa línea militar separaba, los historiadores viraron hacia una caracterización más amplia y laxa de aquella sociedad. Definida como un lugar de encuentros, complejas interrelaciones e intercambios materiales y culturales, la frontera pasó a ser concebida como una zona de contacto. Este cambio de perspectiva implicó, en primer lugar, la ruptura de las barreras que separaban los ámbitos de influencia disciplinar en el tema. De un lado, las sociedades indígenas habían sido tradicionalmente estudiadas por antropólogos y arqueólogos, del otro, la historia rural analizaba la experiencia de la vida en la campaña fronteriza desde la perspectiva de la sociedad criolla. ${ }^{11}$ El cruce de los

\footnotetext{
${ }^{10}$ Entre otros, véase Pratt, Ojos, 1997, y Prieto, Viajeros, 1996.

11 Sobre la evolución de los estudios de las sociedades de frontera, sus resultados, problemas y límites véase Mandrini, "Indios", 1992, pp. 59-74; "Fronteras", 1997, pp. 45-54.
}

límites disciplinares abrió un abanico de temas, entre los cuales se destacan el comercio con los indios, la experiencia de los cautivos, el poblamiento y la colonización, la vida material y la familia. ${ }^{12} \mathrm{Sin}$ embargo, la ampliación del espectro temático y la definición de la frontera como espacio de intensos intercambios no ha resultado todavía (o lo ha hecho en escasa medida) en trabajos que alcancen a integrar a indios y blancos en sus distintos ámbitos de contacto. De esa suerte, pocas investigaciones se han detenido en la forma en que los miembros de estas sociedades, que se alineaban a lo largo de una frontera imaginaria y móvil, experimentaban la presencia, a veces real y a veces tácita, del "otro".

Aunque este trabajo no tiene la pretensión de salvar estos problemas, intenta, a partir de las nuevas concepciones sobre el tema, recrear las experiencias de un puñado de vecinos de una comunidad pequeña que transitaba por el ocaso de la sociedad de frontera. Si bien nuestras fuentes no nos permiten dar cuenta de las relaciones interétnicas que tenían lugar en aquel amplio espacio, creemos que la convivencia de los vecinos de Tandil con las recurrentes amenazas de una invasión indígena revela, al menos parcialmente, la naturaleza lábil de aquella línea imaginaria entre dos mundos en contacto.

\footnotetext{
${ }^{12}$ Los que siguen son algunos de los trabajos que han abordado el estudio de la frontera en esta nueva perspectiva: Ratto, "Negocio", 1994, pp. 89 107; "Indios", 1994, pp. 34-49; Socollow, "Cautivos", 1987, pp. 99-136; Rotker, Cautivos, 1999; Malosseri Costa, "Mujeres", 2000, pp. 87-109; Mayo, Vivir, 2000; Mateo, “Bastardos", 1996, pp. 7-33; Moreno, "Sexo", 1997-1998, pp. 61-84.
} 


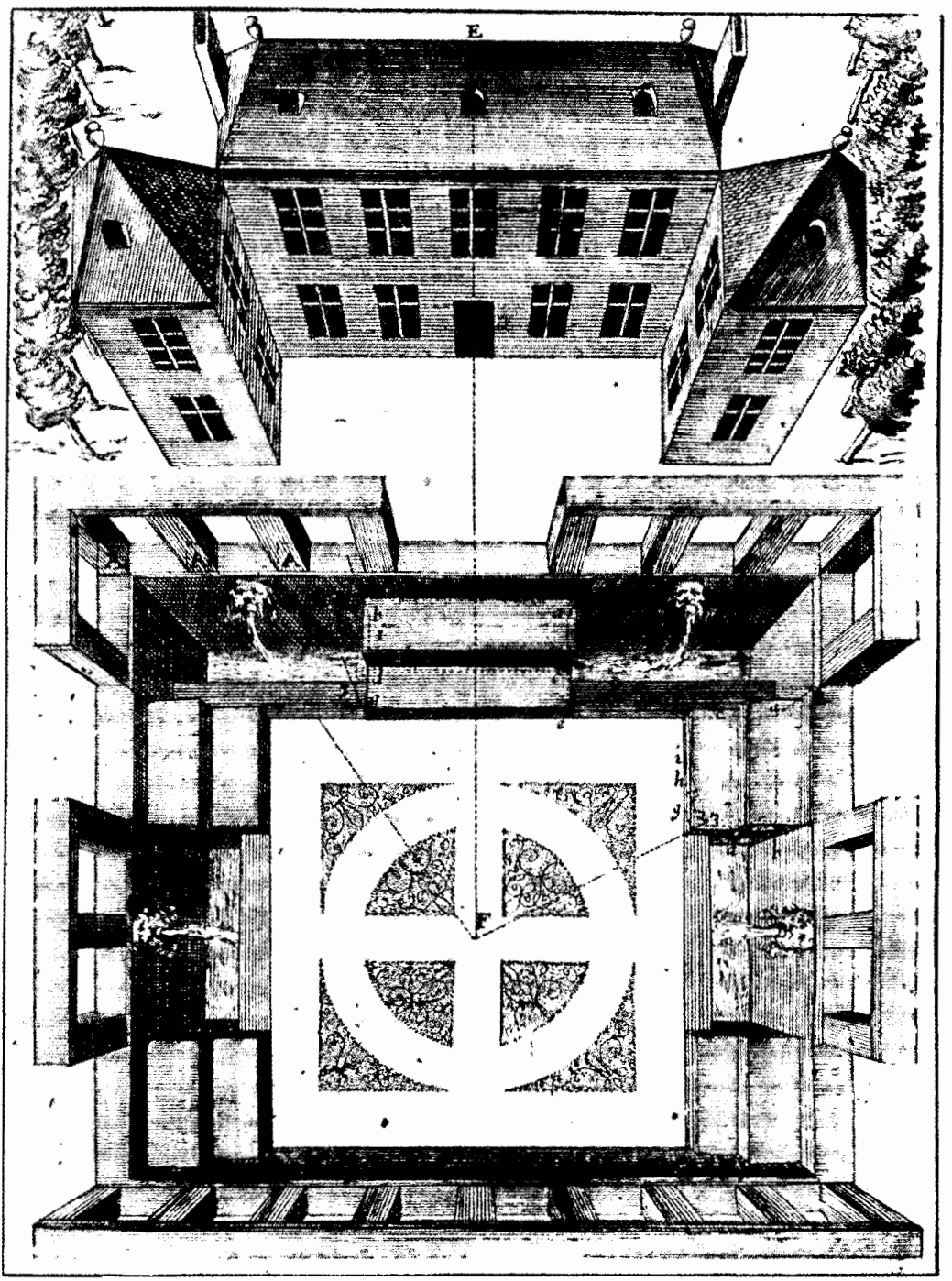




\section{RECUERDO DE UN MALÓN}

Aquella tardecita de fines de abril de 1860 , Dorothea y Grethe, su sirvienta danesa, estaban solas en la casa de la chacra. El viento y los truenos anunciaban la inminencia de la lluvia. Juan se había marchado temprano al pueblo. La noche empezaba a caer. Mientras Grethe contaba los días para que la corneta de la diligencia anunciase la llegada de su prometido entre los pasajeros de Buenos Aires, Dorothea escribía en su diario sobre las noticias de una nueva invasión indígena:

no puedo imaginar que sólo nos separan unas cuantas millas de los salvajes [...] Los que viven en la frontera con los indios anuncian intranquilidad, en cambio aquí no se advierte miedo a un malón, ya que ellos respetan a la milicia.

En el pueblo corrían toda clase de rumores, y las conversaciones de los vecinos evocaban el malón de 1855. Sus notas de abril de 1860 revelan que Dorothea estaba familiarizada con la historia de aquellos días de saqueo, destrucción y muerte.

El sereno del fuerte que llama con su corneta al cambio de guardia parece sonar a guerra, ya que los indios han estado aquí antes de que nosotros llegáramos y la gente teme por un malón como el de hace cinco años atrás cuando asolaron a las casas de la campaña, robando, incendiando y también dejando tantas víctimas. Esta vez, de los alrededores se llevaron los animales que pudieron, entre ellos muchas mulas mansas de trabajo, pero no se animaron a entrar al pueblo igual que en aquella ocasión.

Las correrías y los robos de ganado, la alerta en la guardia del fuerte y las apre- miantes demandas de hombres y caba$\operatorname{llos}^{13}$ que la defensa de los confines de la provincia requería, eran los indicios que sustentaban la cadena de noticias y rumores que reavivaba el recuerdo del malón de 1855, gestado en el turbulento escenario político que precedió a la caída del gobernador Juan Manuel de Rosas, quien había regido los destinos de la provincia entre 1829 y 1852 . En aquella ocasión, esa frontera en tierra adentro desde la cual se anunciaba la intranquilidad de la que nos habla Dorothea, y Tandil, que en el otoño de 1860 se presentaba ante sus asombrados ojos europeos como un lugar en el que todavía podía sentirse a buen resguardo, habían confluido. El espacio híbrido y móvil entre la sociedad blanca y la india, que en épocas de paz operaba como un escenario de intensos intercambios, desapareció de manera temporal cuando el avance de los indios hasta las cercanías del pueblo reveló el resquebrajamiento de los acuerdos que en los años de Rosas habían sostenido el equilibrio entre el mundo blanco y el indígena.

Después de la batalla de Caseros, que terminó con el poder de Rosas en la provincia de Buenos Aires, las nuevas autoridades habían intentado mantener la paz cumpliendo con los compromisos de abastecimiento, establecidos durante su gobierno, conocidos como "negocio pacífico de indios" y centrados en el intercambio de servicios militares de parte de las tribus "amigas" del gobernador por raciones alimenticias. ${ }^{14}$ De tal suerte, en

${ }^{13}$ Como veremos más adelante, Tandil no podría sustraerse por largo tiempo a estas demandas.

${ }^{14} \mathrm{La}$ política de Rosas hacia los indios conjugó una acción negociadora tendiente a captar la amistad de algunas parcialidades y otra de guerra hacia aque- 
marzo de 1852 el juez de Paz Felipe Vela recibió una carta del Ministerio de Gobierno en la que se le ordenaba no innovar en materia de relaciones con los indios y asegurar el envío de 200 yeguas a la toldería de Azul, distante unos cien kilómetros al norte de Tandil (véase mapa), el día 5 de cada mes. ${ }^{15}$ Mas el ganado no alcanzaba para cubrir aquella cuota. En el transcurso del año los estancieros expresaron reiteradamente sus quejas por los apremios que provocaban esas demandas en un campo chamuscado por la sequía del último vetano y asolado por las correrías indígenas que siguieron a las primeras lluvias del otoño, en busca del poco ganado que había quedado en pie. ${ }^{16}$

Cuando la noche de luna llena del 13 de febrero de 1855 el malón que avanzó sobre Azul anunció el recrudecimiento de los ataques en el sur de la provincia de Buenos Aires, el poderoso estanciero Felipe Vela ya no estaba al frente del juzgado de Paz de Tandil. El giro político de la provincia había desplazado del poder a este hombre de inquebrantable fidelidad

Ilas que no aceptaban las condiciones de la paz que el gobierno proponía. Esta política, que tuvo como eje el "comercio pacífico" no fue, sin embargo, uniforme a lo largo de todo el periodo en el que Rosas fue gobernador de Buenos Aires. Sobre la evolución de la misma véase Ratto, "Finanzas", 1998, pp. 241-265.

${ }^{15}$ Luchetti y Spinelli, "Relaciones", 1994, pp. 56-58; Carta del Ministerio de Gobierno de la provincia de Buenos Aires al juez de Paz de Tandil, 23 de marzo de 1852, en Archivo Histórico de la Municipalidad de Tandil (en adelante AHMT), exp. 098.

${ }^{16}$ Cartas dirigidas al presidente de la municipalidad firmadas por varios estancieros de Tandil pidiéndole al juez de Paz que envíe copias al Ministerio de Gobierno de la provincia, 3 de febrero de 1853, 4 de marzo de 1853, y 22 de abril de 1853, en AHMT, exps. 017,068 y 112 . a la causa de Rosas. Carlos Darragueira, un partidario de la nueva dirigencia de la provincia, había reemplazado a Vela. A mediados de febrero, los indios, liderados por el cacique Calfulcurá, se alzaron a su paso por Azul con 2500 hombres, 60000 vacunos y 150 cautivos, y entre fines de marzo y mediados de abril partidas volantes de indígenas avanzaron sobre Tandil "atacando a las estancias del cuartel octavo, arriando cuantas vacas y caballos encontraron y dando muerte a algunos pobladores". 17

La invasión al fuerte de Azul y las incursiones del otoño en las estancias de Tandil pusieron en alerta a la población. Muchos vecinos abandonaron el pueblo y la campaña buscando refugio para sus familias y su ganado en los partidos del norte. Recién entonces el gobierno de la provincia reforzó la defensa de la zona poniendo al frente de la región al comandante Benito Machado, un estanciero y militar que en febrero de 1854 había sido nombrado comandante en jefe de las guardias nacionales de un área que se extendía entre Tandil y la costa del Atlántico. ${ }^{18} \mathrm{Al}$ amparo de una paz aparente, durante el mes de mayo la población masculina regresó a Tandil. Las mujeres y los niños habían quedado a buen resguardo en el norte. Aquel invierno transcurrió en una tensa calma, pero con la primavera floreció el temor a una nueva invasión, anunciada en los partes que llegaban desde la frontera y en las noticias de saqueos a las estancias de Tandil que lindaban con el partido de Azul.

${ }^{17}$ Informe de Juan Casado, alcalde del cuartel octavo del partido de Tandil al juez de Paz Carlos Darragueira, La Colorada, 23 de abril de 1855, en AHMT, exp. 034.

${ }^{18}$ Del Valle, Coronel, 1908 , p. 48. 
El comandante Machado distribuyó sus fuerzas en una vasta zona de la campaña que llegaba hasta las sierras de Volcán y el Cabo Corrientes (véase mapa), pero dejaba a Tandil a cargo de un solo escuadrón. En vano los vecinos advirtieron a la gobernación sobre su precaria situación y en una carta dirigida al ministro de Gobierno reclamaron refuerzos para la defensa. ${ }^{19}$ Mas la falta de respuesta de las autoridades provinciales encontró desamparada a la población cuando la noche del 13 de noviembre las fuerzas de Yanketruz invadieron Tandil. Los indios rodearon el pueblo y mantuvieron el sitio durante varios días, en los que el fuerte, dando refugio a hombres y animales, recuperó el protagonismo perdido durante la pax rosista. Mientras Yanquetruz y su comitiva entraron a parlamentar con el juez de Paz, los 3000 indios que el cacique decía tener a su mando diezmaron las poblaciones y el ganado de los cuarteles que rodeaban al pueblo. $^{20}$ Juan Fulg, sorprendido por el malón en la estancia El Carmen del general Eustoquio Díaz Vélez, recordaba cómo "desde el mirador se veía a la gente huyendo hacia el norte y a los indios en gran número juntando vacas y caballos y arreándolos hacia el sur". ${ }^{21}$

Tras el paso de los indios Tandil quedó sumido en la desolación. En diciembre, cuando al fin parecía que la violencia había cesado, en una carta dirigida al ministro de Gobierno de la provincia, el juez de $\mathrm{Paz}$ Carlos Darragueira describía al pue-

${ }^{19}$ Nota firmada por varios estancieros de los cuarteles II, IV, $\mathrm{V}$ y viII del partido de Tandil dirigida al juez de Paz con pedido de envío al Ministerio de Gobierno de la provincia, 13 de septiembre de 1855 , en AHMT, exp. 154.

${ }^{20}$ Fugl, Memorias, 1989, p. 229.

${ }^{21}$ Ibid., p. 230. blo y a la campaña cercana como "una avanzada en el desierto próxima a ser abandonado por sus muy pocos pobladores". El juez contaba que en "los instantes terribles de la invasión”, pocos fueron los que no se sumaron al éxodo. ${ }^{22}$ Entre ellos se encontraba el estadunidense José Suessy. Los indios atacaron su pulpería y éste fue dado por muerto y abandonado entre los escombros por el alcalde que rastrillaba el cuartel tras la retirada de los invasores. Mas el pulpero todavía tendría vida para contar esa historia. Pocas semanas después de su llegada de Dinamarca, en la velada de bienvenida que Suessy y su esposa le dieron a los Fugl, don José compartió con Dorothea aquella experiencia que lo había puesto en el umbral de la muerte.

El modesto crecimiento que Tandil había alcanzado al amparo del statu quo que reinaba desde la campaña al desierto de 1833 y los acuerdos con los indios amigos sellados por el gobernador Rosas, quedó truncado por el malón. En 1854 las nuevas autoridades de la provincia ordenaron censar la población. Los datos remitidos por la municipalidad a la "mesa estadística" decían que el partido tenía 2899 habitantes, y que en el pueblo, que albergaba a 800 almas, había trece establecimientos comerciales, la mayoría pulperías y almacenes, además de una prensa y lavadero de lanas, tres hornos de ladrillo, tres zapaterías, una carpintería y herrería, una estafeta postal y un destacamento de las guardias nacionales, pero le faltaban "botica, médico, escuela, iglesia y sacerdote”. En la campaña, 250 ganaderos re-

${ }^{22}$ Carta del juez de Paz del partido de Chapaleofú al ministro de Gobierno de la provincia de Buenos Aires, 20 de diciembre de 1855, en AHMT, exp. 198. 
gistraban marcas y había 36 pulperías ${ }^{23}$ a las que abastecían las caravanas de carretas que traían mercadería desde Buenos Aires.

Si los guarismos del censo revelan una expansión incipiente que sería interrumpida por los efectos materiales y sociales del malón, al mismo tiempo advierten de las necesidades del vecindario $y$, sobre todo, de la falta de agentes civilizatorios. En Tandil todavía no había quien se ocupase de la salud, del espíritu, ni de la educación de los pobladores. A fines de 1852, el pulpero Narciso Domínguez, interinamente a cargo del juzgado de $\mathrm{Paz}$, y el alcalde del cuartel primero, el estanciero José Ignacio Gómez, se pusieron al frente de una "recoleta" de dinero y de novillos destinados a la construcción de un templo. Si esta meta debería esperar todavía un largo tiempo, las diligencias de Gómez y Domínguez lograron que las autoridades de la provincia enviasen un fraile a Tandil en los primeros meses de 1854 y se hiciesen eco de otro de sus reclamos: "la pronta aprobación para instalar una escuela pública en este vecindario". ${ }^{24}$ Gracias a los auspicios de una comisión municipal integrada por algunos "vecinos notables que se han hecho cargo de conseguir un maestro y de refaccionar un rancho que se usará de edificio escolar", ${ }^{25}$ la escuela abrió sus puertas en junio de aquel año con una veintena de alumnos. ${ }^{26} \mathrm{Sin}$

${ }^{23}$ Registro Estadístico del Estado de Buenos Aires, 1855, en Archivo General de la Nación (en adelante AGN), sala VII.

${ }^{24}$ Fontana, Tandil, 1947, páginas sin numerar

${ }^{25}$ Carta de la Dirección General de Educación de la provincia al juez de Paz de Tandil, 4 de febrero de 1853, en AHMT, exp. 23.

${ }^{26}$ Sobre la primera escuela de Tandil véase Urdampilleta, "Magna", 2001. embargo, el esfuerzo de aquellos vecinos por asegurar la educación de sus hijos no sería coronado por la continuidad. El éxodo de población causado por el malón obligó a la municipalidad a suspender la enseñanza en noviembre de 1855 por

no haber niños que frecuenten la escuela pues que las invasiones de indios [...] han dejado al pueblo en ruinas y los pocos vecinos que no se han marchado hacia el norte [...] se hallan ocupados en las tareas de reconstrucción. ${ }^{27}$

El año 1856 comenzaba con una población diezmada y temerosa. Hacia el sur la inquietud no cedía y los ecos de la indiada de Nanumcurá asolando a los campos que regaba el arroyo Quequén Grande (véase mapa) alarmaban a los vecinos de Tandil. En octubre de 1857, el regimiento XVII de las guardias nacionales, liderado por el comandante Benito Machado, libró una sangrienta batalla en el paraje "Cristiano Muerto", en la que las fuerzas de Namuncurá fueron derrotadas. Como premio a su desempeño, el gobierno de la provincia bautizó al regimiento con el nombre "Sol de Mayo" y ascendió a teniente coronel a Machado. ${ }^{28}$ De ese modo parecía clausurarse una etapa de conflicto que se había abierto en 1854 y que dejaba un saldo de 25000 bajas entre muertos, heridos y desaparecidos, y una pérdida de 400000 cabezas de ganado. ${ }^{29}$

\footnotetext{
${ }^{27}$ Carta del juez de Paz al jefe del Departamento de Escuelas, don Domingo Faustino Sarmiento, 25 de noviembre de 1855, en AHMT, exp. 020.

${ }^{28}$ Del Valle, Coronel, 1908, p. 52.

${ }^{29}$ Bechis, "Interethnic", 1983, pp. 540-541.
} 
Aunque Tandil recuperó la calma, las secuelas del malón fueron intensas y duraderas. Los pobladores que habían encontrado refugio en el norte tardarían mucho tiempo en regresar. En una carta dirigida al gobernador Pastor Obligado en diciembre de 1855 , el estanciero Felipe José Miguens advertía que las familias que habían buido hacia Dolores veían "lejano el día del regreso a [sus] hogares por no creer seguros sus intereses [...] pues las noticias de invasiones lejos de cesar se sujetan" ${ }^{30} \mathrm{Si}$ es cierto que no sabemos cuántas fueron las víctimas de las incursiones indígenas, cuántos los pobladores que se sumaron al éxodo, ni cuántos nacieron o murieron en esos años, pues en 1855 el fraile suspendió sus anotaciones en los libros partoquiales y terminó su corta misión marchándose del pueblo, ${ }^{31}$ los datos del registro estadístico dan un indicio de las secuelas del malón al revelar que en 1858 Tandil tenía la misma cantidad de pobladores que cuatro años antes. ${ }^{32}$

De la naturaleza del restablecimiento de las relaciones con los indígenas nos da un indicio el comerciante y ganadero An-drés Egaña, intentando retomar la vieja práctica de contratar indios de las parcialidades amigas como peones de campo. En una carta dirigida al prefecto Juan Elguera, Egaña le pedía que intercediese ante

${ }^{30}$ Álvarez y Míguez, "Vida", 1983, p. 10.

${ }^{31}$ Carta de fray Luis Manchini a Carlos Darràgueria, 21 de mayo de 1855, en AHMT, exp. 088. Si bien el cura no expresa claramente las razones de su partida es posible que, como tantos otros pobladores, abandonase el pueblo por temor a una invasión indígena.

${ }^{32}$ El partido tenía 2900 habitantes. Registro Estadístico del Estado de Buenos Aires, Buenos Aires, 1857 en AGN, sala VII. las autoridades de la provincia para que lo autorizaran a conchabar 20 indios de Tapalqué (véase mapa) como peones de la estancia de su suegro, el general Eustoquio Díaz Vélez. Egaña argumentaba que

la ocupación de indios es un bien no sólo para los estancieros sino también para el gobierno, pues estos hombres ocupados y diseminados en distintas partes se concentrarían al trabajo y aurraraían [sic] al Estado algunos pesos porque no me negará que la osiocidad [sic] es madre de todos los vicios. ${ }^{33}$

El prefecto no compartía el punto de vista del estanciero, ya que creía que la contrata de indios amigos en las estancias de los cristianos debilitaba la defensa de la frontera, pues

cuando se los necesite en el Tapalquén será muy dificultoso juntarlos en número suficiente si están [...] en lugares distantes como Tandil, porque si hoy pide Egaña veinte para El Carmen mañana otros estancieros van a pretender lo mismo. ${ }^{34}$

Al parecer, al ministro de Gobierno le resultaron más persuasivas las razones de Egaña que los argumentos de Elguera. Elogiando las reflexiones del ganadero tandilense, el funcionario autorizó el conchabo de los peones indios bajo la salvedad de que si iban a establecerse en territorio blanco debían hacerlo en corto número, "siendo los dueños de los esta-

${ }^{33}$ Carta de Andrés Egaña al prefecto Juan Elguera, El Carmen, 13 de enero de 1858, en AHMT, exp. 059 .

${ }^{34}$ Carta del prefecto Juan Elguera al ministro de Gobierno, Tandil, 23 de enero de 1858, en AHTM, exp. 098. 
blecimientos de campo los responsables por cualquier desorden que puedan causar". 35

A fines de la década de 1850 Tandil comenzaba a mostrar signos de recuperación, al tiempo que el malón se transformaba en una de las representaciones colectivas sobre las que se construía la memoria del pueblo que todavía no tenía cuatro décadas de vida. "Los valientes que en aras de la civilización sucumbieron a los golpes de las inhumanas lanzas de los bárbaros que capitaneaba Ñanquetru" 36 fueron sepultados en una fosa común. En los años que siguieron, los forasteros que visitaban Tandil, los nuevos pobladores que llegaban para avecindarse y los alumnos de la escuela que volvió a abrir sus puertas en 1858 , debían oír una y otra vez la evocación de aquellos días luctuosos. El "panteón cobijado por una humilde cruz" 37 no sólo era el emblema de combates pasados, sino también la advertencia de que en la calma se emboscaban inquietudes futuras.

"UN PEQUEÑO MUNDO AISLADO, EFICIENTE Y TRABAJADOR"

El contexto en el que iban a transcurrir los años de Dorothea Fugl en Tandil estaría atravesado por tensiones de distinta naturaleza que, gestadas en escenarios distantes, repercutirían con diferente intensidad en el mundo local. La guerra con Para-

35 Carta del ministro de Gobierno José Barros Pazos al prefecto Juan Elguera, Buenos Aires, 23 de enero de 1858, en AHMT, exp. 113.

${ }^{36}$ Juldaín Antonio, "El Tandil de hace treinta años", El Eco de Tandil, 11 de mayo de 1884.

${ }^{37}$ Ibid. guay ${ }^{38}$ y el recrudecimiento de las luchas que marcaron el largo camino de la organización nacional, las plagas del cólera y la fiebre amarilla, imaginadas como un engendro de las miasmas de la ciudadpuerto cuyos flujos letales se propagaban por la campaña, o las catástrofes naturales como el terremoto en la ciudad cordillerana de Mendoza, cuyos demoledores efectos despertaron una densa red de solidaridad que reveló la fortaleza de los vasos comunicantes entre las regiones, fueron algunas de las tensiones que, como veremos en las páginas que siguen, movilizarían las angustias, las vigilias o la simple curiosidad de los vecinos de Tandil en las décadas de 1860 y 1870.

Después de que las fuerzas del coronel Machado derrotaran a la indiada de $\mathrm{Na}$ muncurá los rumores de invasión indígena cesaron y la población comenzó a regresar a Tandil. Las preocupaciones de las autoridades locales reveladas por las actas de reunión del consejo municipal y por la correspondencia del juzgado de Paz son testimonio de que un año antes de que Buenos Aires y la Confederación se enfrentaran en la batalla de Cepeda (1859) y las amenazas de los indios trajesen nueva inquietud a la frontera, la comunidad iniciaba una época en la que las energías de los vecinos -al menos de aquellos que controlaban el gobierno municipal- se concentrarían en la resolución de problemas locales. Tandil, al que Dorothea describía como un pequeño mundo aislado,

\footnotetext{
${ }^{38}$ Este conflicto que se extendió un lustro (18651870) enfrentó a Paraguay y su presidente vitalicio, Francisco Solano López, con la Triple Alianza conformada por Brasil, Uruguay y Argentina. Al mando de las fuerzas argentinas estuvo el entonces presidente de la nación, Bartolomé Mitre.
} 
eficiente y trabajador, iniciaría en estos años un lento derrotero que lo iba a alejar de su condición de pueblo de frontera. Sin embargo, ese "curso hacia un futuro halagüeño" estaría signado por la presencia latente del peligro indígena que parecía suspender al pueblo en el pasado.

Removidos de su anclaje en el clima de inseguridad que había reinado en los años que siguieron al malón, en abril de 1858 los vecinos reunidos en el desvencijado edificio municipal retomaban el sendero de la civilización, discutiendo la mejor forma de mantener la limpieza de las calles del pueblo y de ordenar medidas de higiene a los carniceros que, usando sus patios como mataderos, inundaban a la vecindad de "inmundicias y de olores pestilentes". 39 Como la municipalidad no tenía recursos para hacerse cargo de la recolección de basura, se decidió que por "única vez" lo harían los presos, y que en adelante sería la obligación de cada vecino mantener aseado su frente. Se prohibió "echar escombros, basura y desperdicios, así como tener altos los pastizales y dejar crecer cicuta, una yerba conocida por su gran peligrosidad". Además de la limpieza, a los ediles les preocupaba la seguridad de los transeúntes que circulaban por el pueblo después de la caída del sol. La propuesta del consejero Manuel Romero de ordenar a los dueños de casas y comercios que dejasen sus faroles encendidos durante toda la noche hasta tanto la municipalidad pudiese costear el alumbrado público, fue votada favorablemente. ${ }^{40}$

\footnotetext{
39 Acta de reunión de la corporación municipal, 4 de abril de 1858, en AHMT.

${ }^{40}$ Acta de reunión de la corporación municipal, 12 de abril de 1858, en AHMT.
}

Sin embargo, no pocos vecinos hicieron caso omiso de las ordenanzas dispuestas en cumplimiento del "aseo público" y del "bien de este pueblo". El almacenero Patrocinio Ortiz fue multado por negarse a dejar encendidas las dos farolas de la fachada de su local. Por su parte, en la carnicería de Marcial, ubicada frente a la plaza, seguían usando el patio como matadero y tirando "las inmundicias" en un pozo del que salía un olor nauseabundo. Como el carnicero se negaba a faenar los animales "al otro lado del arroyo", la municipalidad decidió multarlo. Si Marcial se avino a limpiar las "inmundicias", se negó a trasladar su matadero, y logró imponer el problema de las carneadas en el orden del día de las sesiones de la Corporación Municipal. El consejero Inocencio Garrido, seguramente el más afectado entre los vecinos por la "dejadés" de Marcial, ya que el patio de su casa lindaba con la carnicería, se mantuvo firme en que las faenas se hicieran lejos del centro del pueblo, mas la mayoría de los ediles sostuvo que la distancia podía dificultar el abastecimiento de carne cuando el mal estado de los caminos impidiese la circulación de las carretas. Finalmente, se resolvió autorizar la faena a diez cuadras de la plaza y crear un depósito "sujeto a las reglamentaciones de higiene pública" en el centro del pueblo. ${ }^{41}$

En el verano de 1860, el lábil andamiaje que soportaba a la realidad social de ese mundo local ocupado en la higiene y la iluminación del pueblo fue conmovido por las amenazas de malón que se anunciaban en las notas recibidas por el presidente de la municipalidad. Pocos

\footnotetext{
41 Acta de reunión de la corporación municipal, 21 de mayo de 1858 , en AHMT.
} 


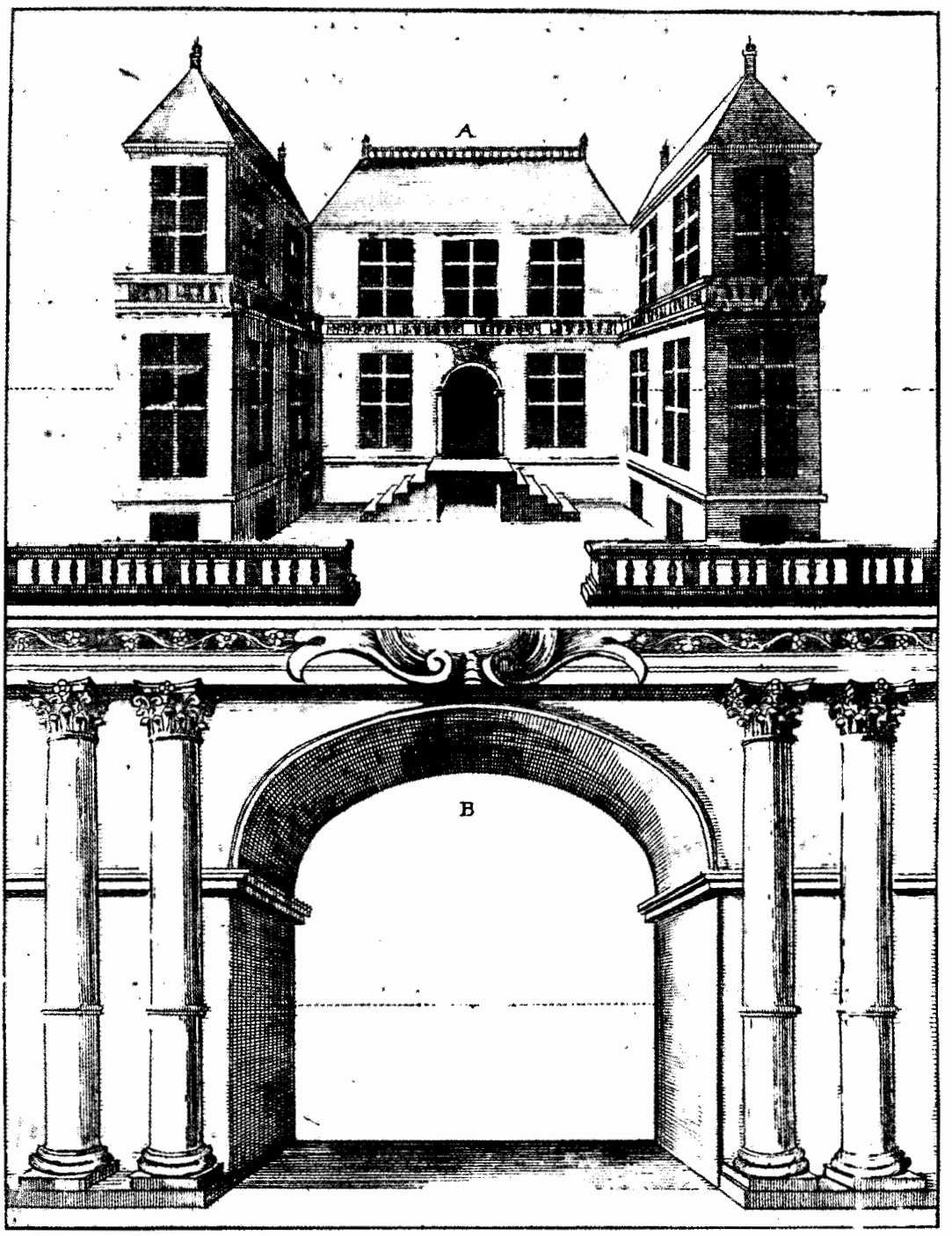


días antes de que Dorothea llegase a Tandil, el coronel Benito Machado le hacía saber al juez de Paz que el gobierno de la provincia había resuelto el urgente enrolamiento de las guardias nacionales del partido

cuanto que los rumores de invasión hacen necesario [...] que se sirva impartir órdenes a los alcaldes para que a la mayor brevedad vengan con todos los hombres que les fuera posible [...] y también le ordeno a usted aprehender a todos aquellos individuos desconocidos de otros partidos que no tengan sus pases correspondientes o que estén vencidos. ${ }^{42}$

La tensión en la frontera se prolongó hasta bien entrado el otoño. A mediados de mayo comenzaban a llegar arreos desde tierra adentro buscando protección en las cercanías de Tandil. Como los rumores de "inquietud entre los salvajes" no se aplacaban, los Fugl decidieron mudarse al pueblo. La chacra era insegura en un ataque indígena y muy fría para que Dorothea, que a esa altura estaba entrando en el cuarto mes de su primer embarazo, pasase allí los meses escarchados del invierno. Los cañonazos que a las once de la mañana del 20 de mayo la sobresaltaron, no anunciaban la ruptura de la calma que había sido, en última instancia, el telón de fondo de unos largos meses de alerta. La salva de cañones era el eco que desde Buenos Aires proyectaban hacia la campaña las novedades políticas de la provincia. En una carta dirigida al juez de Paz, el coronel Benito Machado había or-

${ }^{42}$ Carta del coronel Benito Machado al juez de Paz de Tandil, 21 de febrero de 1860, en AHMT, exp. 049. denado anunciar con estruendo y banderas la llegada del general Bartolomé Mitre a la gobernación de la provincia. ${ }^{43}$

Cuando las laderas de las sierras empezaron tímidamente a reverdecer, recrudeció el desasosiego. La municipalidad anunció a los vecinos la prohibición de que "los individuos particulares pasen en dirección al desierto y crucen la línea de frontera sin permiso". Aquellos que fuesen encontrados boleando sin una papeleta que los autorizara serían destinados al servicio de armas de la provincia. ${ }^{44}$ En el pueblo todos hablaban de la inminencia de una invasión de indios chilenos y los alcaldes recibían órdenes de aprontar a los vecinos con sus caballos de tiro para la defensa de la comarca. ${ }^{45}$ En aquel tiempo, el pulso de la vida cotidiana variaba al ritmo de las novedades. Algunas de ellas ponían una nota de alegría a la sociabilidad de los vecinos, como cuando a mediados de septiembre, los acordes de la debutante banda de música los convocaron a un baile popular en la plaza. Otras evocaban temores del pasado. No había transcurrido un mes desde aquel baile cuando el sonido de la banda fue reempla-

${ }^{43}$ Carta del coronel Benito Machado al comandante del fuerte Independencia (con copia al juez de Paz de Tandil), Tandil, 5 de mayo de 1860, en AIIMT, exp.142. Después de la victoria en la batalla de Pavón, desde la gobernación de Buenos Aires, Mitre ejerció de hecho el mando del país hasta que, en 1862 , fue elegido formalmente presidente de la nación.

${ }^{44}$ Circular del Ministerio de Guerra al juez de Paz de Tandil. Buenos Aires, 22 de agosto de 1860 , en AHMT, exp. 262.

4s Carta del coronel Benito Machado al juez de Paz de Tandil, 6 de septiembre de 1860, en AHMT, exp. 279. 
zado por el seco llamado de los tambores de la guardia. Dorothea anotaba:

¡ahora vienen los indios! [...]. La otra noche tocaron alarma con los tambores para ejercitar a los soldados a tomar las armas con rapidez y todos los gauchos capaces de contribuir en una emergencia pasaban a caballo a gran carrera por las calles del pueblo para ayudar a defenderlo [...] nos dicen que no hay nada que temer [...] la verdad es que me gustaría ver a esos salvajes.

El año terminó entre amenazas, recluta de guardias nacionales y recolección de caballos patrios. Sin embargo, los indios no traspasaron la línea de frontera. En el tórrido verano de 1861, los rumores de malón daban paso a los de revolución. Los ecos de la explosiva situación política nacional que en noviembre de 1860 había tenido una de sus expresiones más dramáticas en el asesinato del gobernador de la provincia de San Juan, llegaban hasta Tandil. Temerosa de que ese clima de creciente tensión perturbase la quietud del pueblo, Dorothea escribía:

Ayer [ 4 de febrero] un soldado dio muerte a un gaucho de una puñalada, y quién sabe si tales actos no se repetirán, ya que se habla de revolución [...] en la provincia de San Juan donde han asesinado al gobernador [...] ¡Qué horror! Toda la república está convulsionada y pensando enviar fuerza militar a San Juan y una proclamación pidiendo a todos vengar este escándalo.

Un par de meses más tarde otra noticia que llegaba desde Cuyo volvía a convulsionar a los vecinos. El 20 de marzo un terremoto había destruido Mendoza. Las autoridades municipales pidieron a las damas que representaban a la Sociedad de Beneficencia en el pueblo que participasen de una campaña de auxilio a "los que han sobrevivido después de la catástrofe que redujo a esa ciudad a escombros y miseria". ${ }^{46}$ Las misias, entre las que se encontraba Dorothea, se organizaron en partidas y recorrieron Tandil con sus alcancías. Dos semanas después del inicio de la campaña, las autoridades municipales enviaban a Mendoza los 15000 pesos que "los vecinos han reunido para quienes no tienen medios para llenar las primeras necesidades de su existencia". 47

$\mathrm{El}$ asesinato del gobernador de San Juan y la catástrofe de Mendoza nos dan indicios de la existencia de una densa red de comunicación entre las regiones que volvería paradojal la condición de "mundo aislado" con la que Dorothea había calificado al pueblo hacía poco menos de un año. Sin embargo, esa expresión (y otras que veremos en las páginas que siguen) parecen sugerir más bien que su representación de Tandil era la de un espacio donde la vida cotidiana transcurría parcialmente al margen de los vaivenes y tensiones que atravesaban el escenario de la política nacional. En general, esas tensiones deben haber sido bastante bien conocidas por los vecinos. Dorothea cuenta de la avidez con que ella y Juan esperaban cada semana el diario de Buenos Aires y las noticias que traían los postillones y

${ }^{46}$ Carta del ministro de Gobierno Juan Gelly y Obes-al juez de Paz de Tandil, Buenos Aires, 1 de abril de 1861, en AHMT, exp. 112; Carta del juez de Paz de Tandil a la inspectora corresponsal de la Sociedad de Beneficencia, Tandil, 5 de abril de 1861, en AHMr, exp. 135.

${ }^{47}$ Acta de reunión de la corporación municipal, 5 de mayo de 1861 , en ibid. 
los viajeros de la diligencia, y menciona que la información oficial que llegaba a la municipalidad pronto empezaba a filtrarse y circular por el pueblo. Si esas noticias contribuían a crear un clima de incertidumbre y a colocar a Tandil en un escenario que desbordaba los límites del mundo local, los efectos más perniciosos de aquellas tensiones parecían -al menos en la perspectiva de Dorothea- tocarlo sólo de modo tangencial.

Cuando la escarcha del invierno empezó a cubrir las calles fangosas del pueblo, los ecos de la catástrofe mendocina habían amenguado, sin embargo, en el diario de Buenos Aires, en la correspondencia oficial y en los comentarios de los vecinos comenzaba a hablarse de otro terremoto, el de la política nacional. En las cartas que el juez de Paz recibía de la comandancia de frontera las presiones para que se cumpliesen las disposiciones del Ministerio de Guerra que ordenaban reclutar a los extranjeros para el servicio de patrulla adoptaban un tono cada vez más urgente. ${ }^{48}$ Cuando la fuerza militar de Tandil fue trasladada al fuerte de Azul, amenazado una vez más por "los bárbaros del desierto", el pueblo quedó con la única protección de la patrulla de extranjeros al mando de un sastre vasco. ${ }^{49}$ Entre tanto, las instancias de conciliación entre

${ }^{48}$ Circular del Ministerio de Guerra a los jueces de Paz de la campaña sur, Buenos Aires, 11 de septiembre de 1861, en AHMT, exp. 427; Carta del Ministerio de Guerra de la provincia al juez de Paz de Tandil, Buenos Aires, 3 de mayo de 1861, en AHMT, exp. 198; Carta del comandante en jefe del Departamento de la Costa, al juez de Paz de Tandil, Buenos Aires, 24 de abril de 1861, en AHMT, exp. 166.

${ }^{49}$ Carta del juez de Paz de Tandil al jefe de la comandancia sur, fuerte Independencia, 21 de octubre de 1861, en AHMT, exp. 569. el Estado de Buenos Aires y el gobierno nacional se habían agotado y ambos bandos veían la guerra como el único recurso. Por esos días, Dorothea anotaba:

¿Qué raro es pensar que nos encontramos tan alejados de aquel mundo donde todo está convulsionado! No me parece posible que toda esa guerra llegue hasta aquí. Se dice que los opositores muy pronto van a vencer en la provincia de Buenos Aires.

La danesa estaba en lo cierto cuando auguraba que la violencia de las disputas políticas nacionales no llegaría hasta Tandil. Sin embargo, el pueblo no fue completamente ajeno a las consecuencias de aquella guerra en la que se dirimía la unidad de la nación. Las tropas del regimiento "Sol de Mayo", apostadas en Azul, fueron incorporadas a una división de caballería que al mando del coronel Machado marchó hacia Salto Argentino para ponerse a las órdenes del general Mitre. ${ }^{50}$

A pesar de que la marcha del regimiento primero a la defensa de Azul y luego a las filas del ejército que enfrentaría a las fuerzas de la Confederación dejó a Tandil con la única protección de una patrulla de civiles, la tranquilidad se mantuvo durante aquellos meses turbulentos. El ritmo de la vida cotidiana se alteró recién a principios de 1862 , cuando las fuerzas del coronel Machado regresaron del frente. Dorothea contaba que, intimidadas por una presencia militar desconocida hasta entonces, las familias

cerramos los postigos de las ventanas y de las puertas de vidrio y sólo espiamos por una pequeña abertura. De aquí en adelante

${ }^{50}$ Del Valle, Coronel, 1908, pp. 62-63. 
habrá que tener buen cuidado de no acercarse demasiado a las ventanas para no llamar la atención de tantos oficiales curiosos que pululan en las calles.

A pesar de las reservas con las que el pueblo recibió a las milicias, muchos vecinos acudieron al desfile alrededor de la plaza y al acto convocado por un ufano coronel Machado recién ascendido a "jefe de la frontera costa sur". En compañía de su esposo y de Grethe, Dorothea fue testigo de aquella parada militar encabezada por

los oficiales que junto al jefe marchaban con magníficos y lujosos uniformes, además de la platería en las riendas, en los aperos de los caballos y en las espuelas. Todo esto seguido de grupos con ropas tan miserables que los hacían parecer forajidos. Pero había pequeñas divisiones de soldados, con mejor vestimenta y medias blancas largas. Por fin llegaban los indios que caminaban agachados, con sus cuerpos casi desnudos, su cabello largo y bien negro atado con una vincha de cinta o un pañuelo doblado. Algunos con una pluma metida en la vincha.

Pocas semanas más tarde la vida del pueblo volvió a su cauce. Después de licenciar a una parte de la tropa y autorizarla "a regresar a su querencia", el coronel Machado se retitó al destacamento de Tres Arroyos, desde donde mantuvo en vilo a los jueces de Paz y a los alcaldes de Tandil, apremiándolos con sus pedidos de hombres y caballos. En noviembre de 1862, pocas semanas después de que Mitre asumiera la presidencia del país, los rumores volvieron a atemorizar a los vecinos. Dorothea, más preocupada por los daños que las lluvias torrenciales de la primavera habían causado en la chacra que por las noticias que llegaban desde la frontera, anotaba:

Dicen que viene un malón de indios que está sólo a 30 leguas de aquí, que quieren vengarse del gobierno en unión con los opositores por la última derrota que sufrieron. Algunas familias han resuelto viajar a Buenos Aires, pero el pequeño Hans Fugl ${ }^{51}$ y yo nos quedamos con "Tata" hasta que sea posible.

En la copiosa correspondencia que en los años 1863 y 1864 llegaba desde Tres Arroyos al juzgado de Paz de Tandil se hablaba del peligro de una invasión de indios ranqueles. Las misivas reconocían que los avisos de malón no eran "oficiales". Sin embargo, aseguraban su carácter "alarmante y verídico" e instaban a las autoridades locales a tomar medidas preventivas en defensa de los intereses de la campaña. ${ }^{52}$ Hacía pocas semanas que la sequía que asoló a Tandil durante el verano de 1864 había empezado a cejar cuando el juez de Paz Ennesto Romero recibió una esquela del coronel Machado urgiéndolo a enviarle "todos los caballos patrios y de marcas desconocidas" que hubiesen quedado en pie en aquel paisaje de pastizales chamuscados y osamentas de animales. ${ }^{53}$

${ }^{51}$ Se refiere a su hijo de un año de edad.

${ }^{52}$ Carta del coronel Benito Machado al juez de Paz de Tandil, Tres Arroyos, 3 de abril de 1863, en AHMT, exp. 176; Carta de Máximo Elía, jefe del regimiento 17 de las guardias nacionales al juez de $\mathrm{Paz}$ de Tandil, Tres Arroyos, 23 de junio de 1863, en AHMT, exp. 278; Carta del mayor Pantaleón Ortiz en nombre de Benito Machado al juez de Paz de Tandil, 3 de julio de 1863, en AHMT, exp. 559.

${ }^{53}$ Carta del coronel Machado al juez de Paz de Tandil, Tres Arroyos, 17 de abril de 1864, en AHMT, exp. 157. 
A pesar de que la premura de Machado auguraba un ataque inminente, las autoridades de la frontera reconocieron que su apreciación se había sustentado en meros rumores, ya que los indios que incursionaban cerca de la línea eran "pacíficos boleadores". ${ }^{54}$ De tal suerte, a mediados del invierno el mayor Paulino Amarante le comunicaba al juez de Paz que

el jefe de la frontera sur ha ordenado licenciar a las guardias nacionales de Tandil y Lobería que desde hace meses se encuentran en la frontera ante la probabilidad de que la invasión que hace tiempo se viene anunciando [...] no se efectúe. ${ }^{55}$

Aunque no sabemos con certeza por dónde circulaban las noticias que envolvían en la incertidumbre a los pobladores civiles y a los militares apostados en los destacamentos de frontera, ${ }^{56}$ parece atinado pensar que los almacenes y las pulperías del pueblo y la campaña fuesen algunos de sus principales centros de propagación. ${ }^{57}$ Si muchas eran especies falsas-como las caracterizó el mayor Amarante en la carta que autorizaba la licencia de las guardias nacionales que citamos arriba-, en general debían contener

\footnotetext{
${ }^{54}$ Por ejemplo, en abril de 1866 , el jefe de patrulla de la frontera sur le hacía llegar una carta del juez de Paz Carlos Díaz en la que desmentía las versiones de una invasión de indios chilenos que circulaban por la campaña sur de la provincia, en AHMT, exp. 269.

55 Carta del mayor Paulino Amarante al juez de Paz de Tandil, 31 de julio de 1864, en AHMT, exp. 320.

${ }^{56}$ Sobre la circulación de rumores véase Kapferer, Rumors, 1990.

57 González Bernaldo, "Levantamiento", 1987, pp. 137-176.
}

elementos de verosimilitud para poder propagarse. Respecto de su origen y de sus portadores, esas especies eran el emergente de comentarios dispares y fragmentarios aportados por distintos actores sociales. Es probable que los portadores de los avisos no oficiales a los que se referían los partes que llegaban al juzgado de paz de Tandil en 1863 y 1864 , fuesen los indios cuyo intenso intercambio fronterizo con los militares criollos se sustentaba en alianzas que tenían la intrínseca debilidad de durar lo que la conveniencia y las posibilidades endógenas de cada una de las sociedades aliadas lo permitiese. ${ }^{58}$ Los mercachifles y los boleadores de las estancias criollas que se adentraban al desierto deben haber regresado al lado blanco de la frontera con su propia cosecha de noticias que luego echaban a rodar por el pueblo. Los diarios, que con cierta regularidad llegaban desde Buenos Aires, y los municipales y jueces de Paz (en varios casos ellos mismos propietarios de almacenes y pulperías) filtrando información oficial, serían otros de los canales de propagación de noticias. Proviniendo estas especies de los indios, de los ocasionales "viajeros" de la campaña, ${ }^{59}$ de los diarios de la capital, o de los comentarios de jueces y consejeros municipales, es claro que su naturaleza, y en particular su veracidad, sería muy diversa. Sin embargo, más allá de la verosimilitud de los mensajes, todos ellos terminaban configurando una densa trama de noticias, dichos y rumores que

${ }^{58}$ Bechis, "Fuerzas", 1998, pp. 293-317.

59 En el AHMT existen evidencias en este sentido en algunas cartas enviadas por viajeros de la campaña al juzgado de paz donde denuncian turbulencia entre los indios y peligro de invasión. Véanse, por ejemplo, los expedientes 576 y 613 del año de 1874 . 
alertaban a los pobladores creando una verdad consensual que respondía al temor a un malón que pudiese comprometer la paz de Tandil.

Si es cierto que esa amenaza que reavivaba la difícil experiencia de 1855 fue el telón de fondo sobre el que se desarrolló la vida cotidiana del pueblo, también lo es que los vecinos iban habituándose a vivir bajo la acechanza de unos "salvajes" que nunca llegaban. En los días turbulentos de noviembre de 1855 el fuerte había recuperado un efímero protagonismo. Gestado como bastión de defensa en el límite del dominio indígena, a casi 40 años de su fundación, cuando la "línea" de frontera se había desplazado lejos de Tandil, fue perdiendo gradualmente su importancia. En los albores de los años 1860 sólo quedaban sus ruinas que, según expresaba el juez de Paz Ernesto Romero en una carta en la que solicitaba autorización para demolerlo, servían de receptáculo a materias corruptibles y entorpecían los proyectos edilicios de un pueblo que pretendía "recorrer la senda civilizadora que conduce a un futuro promisorio" edificando una nueva sede para el juzgado de paz y la municipalidad, un templo, una escuela de varones y otra de niñas. ${ }^{60}$

El gobierno se demoró algo más de un año en autorizar la remoción de aquel "símbolo de incuria" que en sus orígenes había sido una avanzada de la civilización en la vasta llanura que se extendía al sur del río Salado. Si las obras públicas que proyectaba la municipalidad se hicieron esperar por falta de recursos, la demolición

${ }^{60}$ Carta del juez de Paz de Tandil al ministro de Gobierno de la provincia, 15 de marzo de 1864, citado por Fontana, Tandil, 1947, páginas sin numerar. del fuerte, el refugio de muchos de los vecinos que ahora lo veían como un obstáculo para el progreso en un contexto en el que el concepto de civilización había sido resignificado, marcó el inicio de una nueva época en la vida de Tandil. Una época en la que la sociedad de frontera iría dando paso a un mundo menos rústico y más complejo en el que los malones se transformarían en una letanía que llegaba desde tierra adentro.

En marzo de 1865, un mes antes de que las tropas del general Francisco Solano López invadieran la provincia argentina de Corrientes y el gobierno de Mitre le declarase la guerra a Paraguay, los vecinos de Tandil rompieron la monotonía de sus días para involucrase en otra guerra: la del carnaval. Manuel Suárez Martínez, un inmigrante gallego que trabajaba como dependiente de un almacén de ramos generales, relataba en sus memorias aquellos festejos:

El primer carnaval que pasé aquí fue para mí una sorpresa [...] En la trastienda del negocio estaban llenando cáscaras de huevo con agua perfumada que vendían a los aficionados al juego carnavalesco. Tanto insistieron el patrón y su esposa [...] que, a pesar de mi propósito de no jugar al carnaval, salí con cuatro compañeros [...] Recorrimos las principales casas, nos recibieron a balde lleno [...] En lo de Carlota Machado jugaban por la ventana con jarros y mis compañeros bajaron a echarles un balde de agua. Ellas cerraron la ventana y Leopoldo Mansilla les tiró con tal fuerza el balde que se le escapó de la mano y rompiendo vidrios y barrotes pasó a la parte de adentro [...] pasamos a la casa del juez de Paz pues jugaban él, la señora y otras amigas. Aquella casa se había convertido en un lago. Comedor, sala, dor- 
mitorios, todo estaba lleno de agua que corría por el zaguán hasta la calle. ${ }^{61}$

Si con la guerra del Paraguay volvió la intranquilidad a la frontera, en Tandil sus efectos se advirtieron sólo en los pedidos de caballos patrios para el frente que empezaron a llegar al juzgado de $\mathrm{Paz}$ en los últimos meses de 1865. Mas la seguridad en la campaña sur todavía parecía a buen resguardo. Cuando el presidente Mitre le declaró la guerra a Paraguay, el coronel Machado le manifestó su intención de participar, pero el presidente le ordenó permanecer en su campamento y velar por la seguridad de la frontera. ${ }^{62}$ En 1866 esa línea, cuyo trazado se engrosaba en épocas de conflicto mientras que en tiempos de paz no era más que un difuso límite cultural y geográfico, las prácticas comerciales todavía atraían a los indios hacia el mundo de "cristianos". ${ }^{63}$ En una nota enviada en septiembre desde el campamento de Tres Arroyos, el comandante de la frontera le pedía al juez Carlos Díaz que recibiese al cacique chileno Guanchiquer, quien en compañía de Calfulcurá "pasa hasta ese pueblo a vender sus tejidos, sal y demás con veinte y tantos indios. Mando un oficial en esta compañía para que en su ida y regreso no haya desorden." 64

${ }^{61}$ Suárez Martínez, Apuntes, 1993, p. 154.

${ }^{62}$ Carta de Bartolomé Mitre a Benito Machado, Buenos Aires, 16 de abril de 1865. Transcrita por Del Valle, Coronel, 1908, pp. 82- 83.

${ }^{63}$ Sobre el comercio entre indios y blancos y sus transformaciones en el siglo XIX, véase la nota 12 .

${ }^{64}$ Carta de la comandancia de la frontera sur al juez de Paz de Tandil, Tres Arroyos, 8 de septiembre de 1866, en AHMT, exp. 493.
Es probable que sea ésta la visita a la que se refiere Suárez Martínez en sus memorias cuando cuenta que

llegó a Tandil una comisión de tierra adentro [integrada] por el gran Calfulcurá, rey del desierto, algunos caciques, entre ellos un chileno joven e impetuoso que por primera vez trasponía la frontera [...] Después de la acostumbrada presentación a las autoridades con ceremoniosas manifestaciones de paz y fidelidad, acudieron con sus productos a las casas de comercio para venderlos o trocarlos por víveres, tabaco, cuchillos, etc. y así aprovisionar sus alforjas. Al llegar la comisión a nuestra casa, después de entrar el arrogante Calfulcurá con su corte de caciques menores, lo hizo también el mocetón chileno que observaba la variedad de artículos expuestos. ${ }^{65}$

A pesar de su escasa familiaridad con las prácticas de ese mundo "semisalvaje" al que había llegado hacía poco más de un año, Suárez Martínez advertía la frágil naturaleza de la amistad entre indígenas y cristianos:

Los indios llegaban al pueblo para cambiar matras y ponchos pampas de vivos colores y dibujos típicos [...] prendas de plata [...] "quillangos" o plumas de avestruz, al par que se informaban de las condiciones de seguridad de la frontera, de la situación política del país, de la distribución de las haciendas, recorriendo nuevamente las sendas y adquiriendo la seguridad de orientación en las travesías hacia el desierto para lanzar sus terribles malones que burlaban la guarnición de la frontera y caían como un rayo so-

${ }^{65}$ Suárez Martínez, Apuntes, 1993, p. 169. 
bre las zonas más pobladas de haciendas por los caminos estudiados de antemano. ${ }^{66}$

Las impresiones del español no eran desacertadas. A sabiendas de que las necesidades militares de la guerra con Paraguay habían debilitado la defensa de la frontera, en 1866 "el rey del desierto" lideró a unos 500 indios ranqueles que incursionaron en el sur de Córdoba capturando 10000 cabezas de ganado, matando a 25 blancos y llevándose a 70 cautivos. ${ }^{67} \mathrm{~A}$ mediados de octubre, el jefe de las guardias nacionales de Tandil y Lobería recibió una nota del coronel Antonio López Osornio, que en el otoño había reemplazado al coronel Machado en la comandancia de frontera de la costa sur, en la que le comunicaba que

el cacique Calfulcurá da cuenta de una invasión de indios ranqueles que debe tener lugar en la frontera de Córdoba y que quizá alcance hasta la del mando de usted. Por lo que es urgente necesidad de que usted mande la fuerza que tenga reunida no sólo por la anunciada invasión sino para trabajos que se están practicando en este nuevo campamento. ${ }^{68}$

La inseguridad volvió a la provincia de Buenos Aires en 1868 y se recrudeció en los años siguientes, desembocando en el malón de la indiada de Calfulcurá a

${ }^{66}$ Ibid., p. 172.

${ }^{67}$ Walther, Conquista, 1964, pp. 300 y ss.

${ }^{68}$ Carta del comandante de la frontera sur al jefe del regimiento 17 de las guardias nacionales, Quequén Salado, 13 de octubre de 1866, en AHMT, exp. 572. Esta cita, y la de la nota 67 , ilustran bien nuestra hipótesis de que parte de los rumores que circulaban deben haberse forjado con información aportada por los indios.
Bahía Blanca y Tres Arroyos en $1870 ;{ }^{69}$ en la sublevación indígena de Tapalqué en mayo de $1871,{ }^{70}$ y en la "Gran Invasión" de 1875 liderada por Namuncurá, que llegó muy cerca de Tandil cuando los indios volvieron a atacar Azul dejando 400 víctimas y alzándose con 500 cautivos. ${ }^{71}$ Con el telón de fondo de la turbulencia en la frontera, el juez de Paz y los municipales seguían ocupándose de las necesidades del pueblo.

En el verano de 1868, la epidemia de cólera fue la amenaza más apremiante que los vecinos debieron enfrentar. La municipalidad ordenó "limpiar de inmundicias la ciudad [...] la chanchería del danés Antonio Wolf, ubicada en un lugar demasiado céntrico" fue clausurada hasta que terminase la peste, los bailes y los velatorios fueron suspendidos y las clases interrumpidas por 80 días. En abril, cuando parecía que el flagelo había cesado, el maestro Antonio Lambín pedía autorización para "que se dé por terminada esa clausura y no se hallen por más tiempo los niños sin la instrucción necesaria". 72 Los dos médicos del pueblo, el italiano José Fuschini y el francés Luis Cornille, encabezaron una campaña de prevención e higiene que ordenaba a los alcaldes no enviar cadáveres al cementerio "por ser preferible darles sepultura a campo abierto". ${ }^{73}$

69 Walther, Conquista, 1964, pp. 331-332.

${ }^{70}$ Carta de la comandancia del fuerte Belgrano al jefe accidental de la frontera sur, fuerte Belgrano, 7 de mayo de 1871, en AHMT, exp. 215.

${ }^{71}$ Bechis, "Interethnic", 1983, p. 581.

${ }^{72}$ Carta del Antonio Lambín al presiclente de la municipalidad de Tandil, 12 de abril de 1868, en AHMT, exp. 105.

${ }^{73}$ Carta del juez de Paz de Tandil al alcalde del cuartel primero Nicanor Elejalde, Tandil, 4 de marzo de 1868, en AHMT, exp. 064. 
Los soldados del destacamento de la guatdia, ayudados por los presos y la policía, conformaron la cuadrilla que limpió el campo santo de las ropas y colchones que los dolientes de los coléricos abandonaban junto a sus muertos para alejar de sus casas el peligro de contagio. La municipalidad ordenó también que durante el tiempo que durase la epidemia, Pedro Hegoburu, un vasco pocero que abría fosas en el cementerio, debería cumplir escrupulosamente las disposiciones para el enterramiento de cadáveres: "a un metro de profundidad y en un baño de cal". Según una crónica de la época, presas del pánico, algunos vecinos abandonaron el pueblo. ${ }^{74}$ Sin embargo, las consecuencias de la peste fueron poco dramáticas. Aquel verano el cólera se cobró algo menos de una decena de víctimas. ${ }^{75}$

A pesar de la peste, de la alarma en la frontera y del temor a un nuevo ataque indígena, en los años finales de la década de 1860 Tandil experimentó un crecimiento de población y una diversificación social y económica que quedaría reflejada en los resultados del primer censo nacional de población. ${ }^{76}$ En el año que si-

${ }^{74}$ Citado por Fontana, Tandil, 1947, páginas sin numerar.

${ }^{75}$ Es posible que haya habido más muertes por la misma causa que no quedaron registradas, ya que el número total de decesos de 1868 es superior al de los años precedentes. Véase Álvarez y Míguez en "Vida", 1983, p. 19. Los autores elaboraron un cuadro que muestra las muertes por años discriminadas según sus causas y allí es posible observar que, por ejemplo, en 1865 se produjeron 139 decesos; en 1866, 152; en 1867, 163. En el año de la peste las muertes treparon a 242 y descendieron a 212 en 1869.

${ }^{76}$ Según los datos del censo de 1869 , Tandil tenía 4870 habitantes, de los cuales $15.7 \%$ eran ex- guió a la epidemia de cóleta, en la campaña vivían 4870 personas, y el pueblo albergaba a 2181 almas, entre las que la presencia de extranjeros (especialmente españoles y vascos) y de mujeres y familias era cada vez más notoria. ${ }^{77}$ De paso por Tandil, el viajero francés $H$. Armaignac, que recorrió la pampa entre 1869 y 1874 , lo describía como un lugar "donde hay toda clase de comercios [...] poco lujo aunque bastante comodidad y en algunos lugares hasta he oído tocar el piano". ${ }^{78}$

La expansión se reflejaba en la decisión de las autoridades locales de mejorar el diseño urbano abriendo nuevas calles, cercando la plaza y colocándole faroles de colores "en donde se reúnen las familias los jueves y domingos de retreta para observar la banda". Las nuevas calles no podían continuar alumbradas gracias a la buena voluntad de los vecinos que dejaban encendidos los faroles de sus casas y negocios durante toda la noche. En 1863 , el procurador municipal Francisco Rodríguez le escribía una larga carta al ministro de Gobierno en la que, entre otros reclamos, mencionaba que la municipalidad tenía un proyecto de alumbrado público que no podía costear sin la cola-

tranjeros, en su mayoría españoles y franceses (detrás de esta denominación del censo se ocultaban los vascos, que tenían importante presencia en el pueblo desde los años 1850). Entre esta población diversificada también había migrantes de otras provincias argentinas, en especial de Santiago del Estero. Sobre la estructura demográfica de Tandil en el siglo XIX véase Álvarez y Míguez, "Estructura", 1984, pp. 115-132.

${ }^{77}$ Según los datos del censo de 1869, en Tandil había 122 hombres por cada 100 mujeres. En el censo anterior, el de 1854, los extranjeros representaban $6.2 \%$ de la población y la tasa de masculinidad era de 140.

${ }^{78}$ Armaignac, Viajes, 1974, p. 108. 

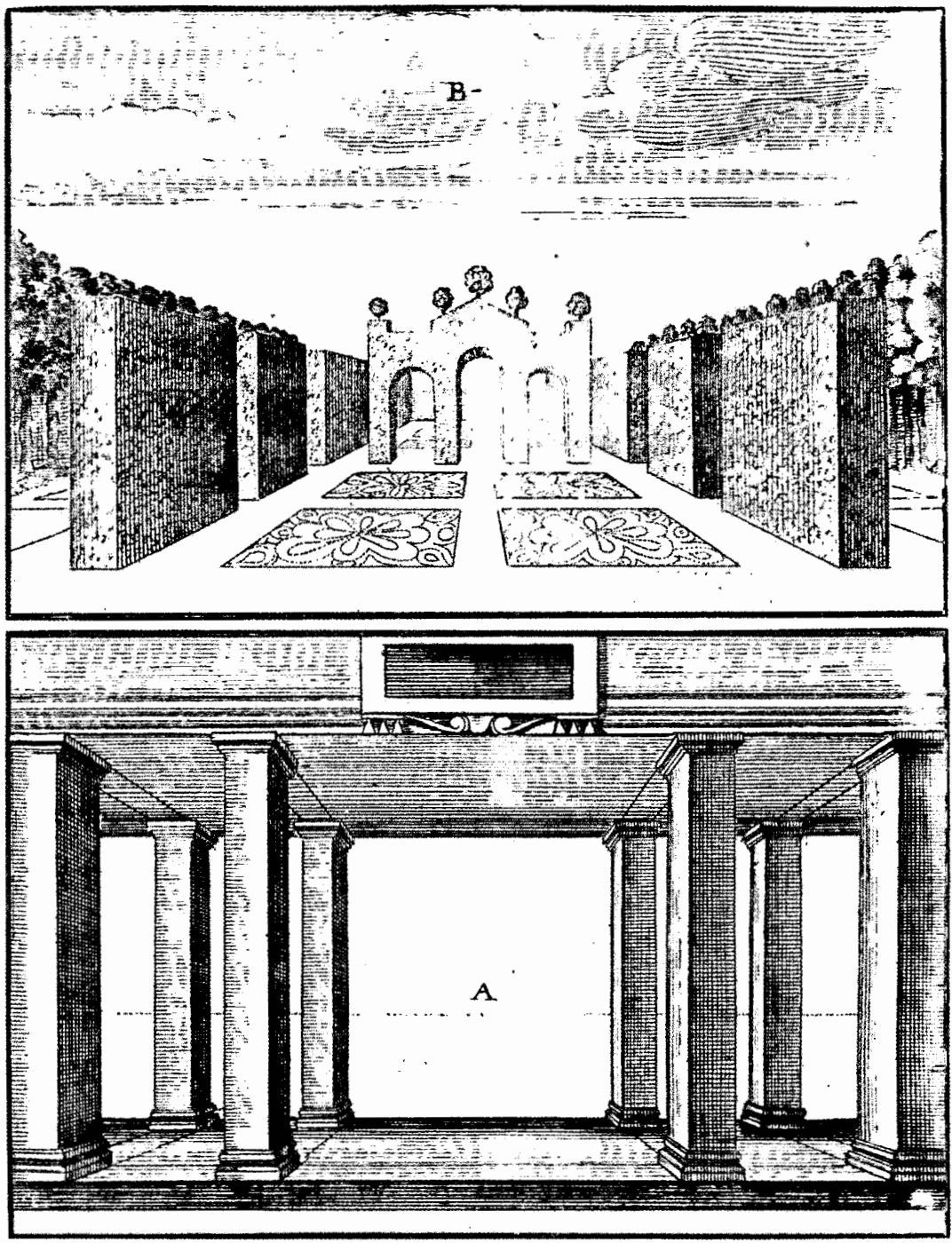
boración de la gobernación. Seis años después, cansados de esperar que las autoridades de la provincia enviasen el dinero que habían prometido en su respuesta a la carta remitida por Rodríguez, los vecinos decidieron que "contando con una subvención de la municipalidad para comprar cincuenta faroles y para los gastos de instalación [...] y con las mensualidades que se cobren a los frentistas" sería posible instalar el alumbrado. ${ }^{79}$ Pasó algo más de un año hasta que las farolas se encendieran por primera vez y las remozadas calles del pueblo se iluminasen "desde la oración hasta la una de la madrugada". ${ }^{80}$

Como la distribución de solares municipales para construcción de casas y fondos de comercio había aumentado tanto, en 1871 escasearon los ladrillos, y algunos beneficiarios de lotes no pudieron poblarlos en los términos que fijaba la ordenanza municipal. Los seis hornos que había en el pueblo no daban abasto con las demandas, por lo que hacia el final del año varios vecinos pidieron prórroga a las autoridades, entre ellos el hotelero bearnés Blas Dhers, quien decía no haber podido edificar el solar que "me fuera cedido en agosto por la falta de ladrillos que es de dominio público". ${ }^{81}$ Mas la escasez de materiales de construcción no era el único indicador del crecimiento de Tandil. A pesar de su importancia como centro comercial en una vasta zona de la campaña, hasta los albores de la década de 1870 en

${ }^{79}$ Acta de reunión de la corporación municipal con los vecinos de Tandil, 28 de febrero de 1869 , en AHMT, exp. 073.

${ }^{80}$ Ordenanza municipal citada por Fontana, Tandil, 1947, páginas sin numerar.

${ }^{81}$ Citado por Iriani Zalakain, Hacer, 2001, p. 161.

TANDIL, EL OCASO DE LA SOCIEDAD DE FRONTERA el pueblo aún no había banco. Después de un año de gestiones, en diciembre de 1871 el juez de Paz Miguel Figueroa recibió una nota en la que el directorio del Banco de la Provincia anunciaba la inauguración de una sucursal en Tandil que abriría sus puertas al público el 2 de enero de 1872 .

Las autoridades municipales decidieron organizar un baile en la víspera para celebrar la llegada al pueblo de este nuevo signo de progreso que en adelante salvaría a muchos vecinos de la incomodidad de tener que viajar hasta Azul cada vez que necesitaban hacer una transacción bancaria. Sin embargo, el baile no llegaría a realizarse, pues el día de Año Nuevo una banda de gauchos armados que respondía a las órdenes de un oscuro personaje apodado "Tata Dios" protagonizó un estallido xenófobo asesinando a más de 30 vecinos, en su mayoría inmigrantes. ${ }^{82}$ La masacre enlutó al pueblo, que había imaginado la fiesta de inauguración del banco como una ocasión para clausurar un año signado por el miedo a que la fiebre amarilla que asolaba a Buenos Aires se propagase por la campaña.

En el verano de 1871 la muerte de un comerciante porteño de paso por Tandil puso en vilo a la población. El doctor José Fuschini aseguraba que la peste era la causa del deceso. La experiencia de la reciente epidemia de cólera fue evocada en las prevenciones adoptadas por el "consejo de la peste". Los ediles municipales, el juez de Paz, los médicos y un puñado de comerciantes conformaban este consejo preocupado por "combatir rigurosamente

${ }^{82}$ Un relato detallado de la matanza liderada por el "Tata Dios", en Nario, Tata, 1976; Santos, "Revuelta", 1995; Lynch, Massacre, 1998. 
el punible abandono en materia de aseo y limpieza al que se entregan tantos habitantes de este pueblo". Las cuatro patrullas de higiene en que se dividieron los integrantes de este "órgano de profilaxis", visitaban a los vecinos de hogares humildes para instruirlos sobre la prevención de la fiebre e insistir en "la importancia de la recolección de la basura y de las carpidas escrupulosas para evitar la propagación del mal", que terminaría cobrándose a una sola víctima: el infortunado pasajero porteño.

El fantasma de la peste había demorado el viaje de los Fugl a Dinamarca. Hacía tiempo que Dorothea quería regresar a Lolland para visitar a su familia. Después de diez años de ausencia soñaba con ver a sus padres, compartir con ellos la experiencia de su vida en la frontera y presentarles a Juancito, Metta y Elena, sus tres hijos nacidos en Argentina. Antes de embarcar con rumbo a Europa, los Fugl planeaban quedarse unos días en Buenos Aires para bautizar a las niñas, que habían sido sólo "cristianadas en socorro" por Juan, pues en Tandil aún no había pastor protestante. Mas el riesgo de contagio los obligó a esperar hasta que la fiebre amarilla cesara. El inesperado desvío de la agenda familiar creó la ocasión para que Dorothea cumpliese con su deseo de "conocer a los salvajes".

Juan solía viajar a Azul a hacer trámites en el banco y a vender harina en los almacenes del pueblo adonde también comerciaban los indios. Hacía tiempo que, sabiendo de las inquietudes de Dorothea, uno de los almaceneros a los que frecuentaba le había ofrecido guiarlos hasta la toldería de "su amigo, el cacique Calefukién”. En compañía de sus tres hijos y de otra familia de inmigrantes daneses, los Fugl viajaron a Azul y se alojaron en un hotel frente a la plaza. Al despuntar el alba, guiados por un dependiente del almacenero azuleño, emprendieron su marcha tierra adentro pertrechados con yerba, azúcar y tabaco para obsequiar a los indios. En cuanto Calefukién ("un gordo no muy aseado [...] que hablaba castellano con cierta dificultad") supo que venían en son de paz, los recibió en su casa, una construcción de ladrillo que le había obsequiado el coronel Benito Machado "en prenda de la amistad que los unía". Mientras los hombres tomaban mate, Dorothea fue guiada por un indio al toldo de las esposas del cacique. Entre las cuatro mujeres que se encontraban allí, había "una cautiva como de cuarenta años que había sido raptada en su juventud, que dijo no tener deseo de regresar a la civilización" y que ofició de lenguaraz para que Dorothea pudiera comunicarse con las otras. ${ }^{83}$ Antes de que cayera la tarde, los visitantes emprendieron el regreso. Al día siguiente, el cacique mandó una comitiva a Azul para que despidiesen en su nombre a los Fugl. Cuando aquella mañana Juan y Dotothea entraron a la confitería del hotel, encontraron a los indios "vistiendo sus mejores galas en compañía de un intérprete y de una numerosa escolta". En sus memorias, Fugl recuerda que les convidaron

con licor y masas y se mostraron muy sobrios y educados [...] intercambiamos los saludos más amistosos, tomando el indio mi mano que apretaba sobre su corazón asegurándonos amistad y lealtad y despidiéndonos hasta una nueva vista.

${ }^{83}$ Sobre el tema del cautiverio de blancos en la sociedad indígena véase la nota 12 . 
Tiempo después, en una pulpería de Tandil Juan se cruzó con Calefukién y sus indios, que habían llegado al pueblo para comerciar y "después de unas cuantas copas de aguardiente se disponían a visitar al coronel Machado antes de regresar al Azul".

Dorothea conoció a los "salvajes" en unas circunstancias bien diferentes de las que había imaginado en aquellos días de la primavera de 1860 , cuando el llamado de los tambores del fuerte anunciaba la inminencia de un ataque indígena. En la excursión a la toldería, se parece a una viajera que con una mirada etnográfica se adentra en el corazón de un mundo que estaba fuera de su universo cultural. Empero, en su caso, ese mundo no podía resultarle completamente ajeno después de haber vivido más de una década en la frontera. Quizá lo que la atraía hacia él fuese el vértigo de arriesgarse más allá de la "línea" donde comenzaba un espacio que para ella representaba el monopolio de control indígena (aunque se tratase de parcialidades "amigas"). En sus memorias, Juan cuenta que durante el trayecto entre Azul y "tierra adentro" su esposa se mostró segura y entusiasmada, sin embargo, a medida que se acercaban a la toldería, "al ver que los indios hacían movimientos hostiles y tenían actitudes hasta amenazantes [...] me pidió que nos volviésemos". Una conjunción de fantasía y temor movilizó a Dorothea, que quizá vivió la excursión como la ocasión para acrecentar el capital de experiencias con que iba a presentarse ante su familia cuando la fiebre amarilla cejara y pudiese volver a $\mathrm{Di}$ namarca desde la frontera, un lugar al que su padre había imaginado "lleno de salvajes que se devoran a los humanos".

\section{CONSIDERACIONES FINALES}

Aun en la paz, los indios que se mostraban tan "hospitalarios y amigables" podían transformarse en aquellos "salvajes" que asolaron Tandil en 1855. ¿Era eso lo que temía Dorothea durante su excursión a la toldería de Azul? Es posible, aunque no parece menos cierto que a esa altura de su vida en Argentina debía conocer bastante bien la lógica de las relaciones entre ambas sociedades. ${ }^{84}$ Los indios encarnaban algo más que una amenaza. Eran aquellos que vio desfilar alrededor de la plaza cuando el regimiento "Sol de Mayo" regresó victorioso de los campos de Pavón; eran las comitivas que llegaban ocasionalmente a comerciar a los almacenes del pueblo; eta la curandera Petrona Rojas, una india pampa que vivía en una estancia del cuartel primero cuya "medicina" curó a la pequeña hija de su amiga Marie Larsen de un mal que la ciencia del doctor Fuschini no había podido remediar.

A los pocos días de llegar a Tandil, Dorothea supo que en el mundo de la frontera su tiempo estaría signado por el toque del clarín de la guardia del fuerte. Ese sonido que ordenaba su día también era la advertencia de que en la vida de la campaña sur se alternaban épocas de paz. y tiempos de guerra en los que los pobladores eran conmovidos por las invasiones de los indios. Cuando en 1875 los Fugl se marcharon de Tandil para radicarse en Dinamarca, ese escenario había cambiado.

${ }^{84}$ Sin que ello implicase un conocimiento detallado de los diferentes grupos de indígenas que aparecen en nuestro relato, ni de las relaciones entre dichos grupos, o entre cada uno de ellos y la sociedad blanca. 
El fuerte había sido demolido, el clarín de la guardia había dejado de sonar, la frontera militar se había alejado del partido, la invasión siempre anunciada nunca había llegado y el último malón, el de 1855 , se había transformado en una memoria sólo compartida por quienes lo habían vivido.

Tanto la paz como la guerra habían hecho de la frontera mucho más que aquella "línea" de la que hablaban las cartas y los partes que el coronel Machado enviaba a los jueces de Paz de Tandil. Si el comercio fue el camino por el que más regularmente habían transitado las relaciones entre ambos mundos, no había sido por cierto el único. Las "visitas" desde y hacia la sociedad indígena, ${ }^{85}$ la participación de los lanceros indios en las batallas por la unidad nacional y la contrata de indígenas en las estancias criollas, ${ }^{86}$ deben haber sido otras importantes fuentes de una interacción entre "cristianos y salvajes" que creaba las condiciones para articular una zona de contacto que inexorablemente incluía al "otro". En las dos décadas que mediaron entre el malón y el regreso de Dorothea a Dinamarca, ese "otro", que se expresaba en forma de violencia latente o de pacífica (y ocasional) presencia, fue el telón de fondo de la vida cotidiana de los vecinos de Tandil. Esa vida transcurrió en gran parte signada por

\footnotetext{
${ }^{85}$ Recordemos a Dorothea visitando a Calefukién, pero también a Calefukién visitando en Tandil al coronel Machado, o a Yanketruz y su escolta entrando al pueblo durante el malón de 1855 a ver al juez de Paz y "tomar una copa con los cristianos mientras su gente trabajaba" (según el relato de Fugl, Memorias, 1989, p. 231).

${ }^{86}$ Sobre la contrata de indios amigos véase Ratto, "Fronteras", 2002.
}

los rumores que anunciaron -por más de dos décadas- un ataque inminente de los indios. Si es cierto que ese eco del desierto tuvo un desenlace anticlimático, también lo es que fue el epítome de una época: la del ocaso de la sociedad de frontera.

\section{ARCHIVOS}

AGN Archivo General de la Nación

AHMT Archivo Histórico de la Municipalidad de Tandil

\section{HemERografía}

\section{El Eco de Tandil, 1884.}

\section{BiBLIOGRAFÍA}

-Álvarez, Norberto y Eduardo Míguez, "De la vida y la muerte en una sociedad de frontera. Un análisis de la mortalidad en Tandil (Bs. As.) en la segunda mitad del siglo XIX" en Actas de las I Jornadas de Historia Argentino-Americanas, Tandil, 1983.

, "La estructura socio-ocupacional de Tandil 1869-1895" en Actas de las VI Jornadas de Historia Económica, Córdoba, 1984.

-Armaignac, H., Viajes por las pampas argentinas. Cacerias en el Quequén Grande y otras andanzas, 1869-1874, Eudeba, Buenos Aires, 1974.

-Bechis, Marta, "Interethnic relations during the period of nation-State formation in Chile and Argentina. From Sovereing to Ethnic", tesis de doctorado, Graduate Faculty, New School for Social Research, Nueva York, 1983.

—_ " "Fuerzas indígenas en la política criolla del siglo XIX" en Noemí Goldman y Ricardo Salvatore, Caudillismos rioplatenses. Nuevas miradas a un viejo problema, Eudeba, Buenos Aires, 1998. 
-Bjerg, María, Entre Sofie y Tovelille. Una bistoria de la inmigración danesa en la Argentina, 1848-1930, Biblos, Buenos Aires, 2001.

_, "Imágenes de familia en la frontera. El mundo de Dorothea Fugl en Tandil en la segunda mitad del siglo XIX" en VIII Jornadas Interescuelas-Departamentos de Historia, Universidad Nacional de Salta, Salta, 18-21 de septiembre de 2001 .

-Bonaudo, Marta (coord.), Liberalismo, Estado y orden burgués (1852-1880), Sudamericana, Buenos Aires, 1999 (Colección Nueva Historia Argentina, tomo 4).

-Del Valle, Antonio G., El coronel don Benito Machado. Apuntes bistóricos, edición del autor, Tandil, 1908.

-Fontana, Osvaldo, Tandil en la bistoria, edición del autor, Tandil, 1947.

-Fugl, Juan, Memorias de Juan Fugl. Vida de un pionero danés durante 30 años en Tandil, 18441875, traducidas pór Alice Larsen de Rabal, edición de la autora, Tandil, 1989.

-González Bernaldo, Pilar, "El levantamiento de 1829: el imaginario social y sus implicaciones políticas en un conflicto rural", Anuario IEHS, Universidad Nacional del Centro, núm. 2, 1987, Tandil.

-Gorostegui de Torres, Argentina. La organización nacional, Paidós, Buenos Aires, 1969.

-Iriani Zalakain, Marcelino, Hacer América. Los vascos en la pampa búmeda, Argentina (18401920), Universidad del País Vasco, Bilbao, 2001.

-Kapferer, Jean Noël, Rumors. Uses, interpretations, and images, Transaction Pub., New Brunswick, 1990.

-Luchetti, Javier y Guillermo Spinelli, "Relaciones blanco-indígenas en la frontera Chapaleofú, Azul y Tapalqué, 1840-1852", tesina de licenciatura, Facultad de Humanidades-Universidad Nacional del Centro, Tandil, 1994.

-Lynch, John, Massacre in the Pampas, 1872. Britain and Argentina in the Age of Migration, University Press, Oklahoma, 1998.
-Mandrini, Raúl, "Indios y fronteras en el área pampeana (siglos XVI-XIX). Balance y perspectivas", Anuario IEHS, Universidad Nacional del Centro, núm. 7, 1992, Tandil.

, "Las fronteras y la sociedad indígena en el ámbito pampeano", Anuario IEHS, Universidad Nacional del Centro, núm. 12, 1997, Tandil.

-Malosetti Costa, Laura, "Mujeres en la frontera" en Fernanda Gil Lozano et al. (coord.), Historia de las mujeres en la Argentina, colonia y siglo XIX, Taurus, Buenos Aires, 2000.

-Mateo, José, "Bastardos y concubinas. La ilegitimidad conyugal y filial en la frontera pampeana bonaerense (Lobos, 1810-1869)", BoLetín del Instituto de Historia Argentina y Americana "Dr. Emilio Ravignani", núm. 13, primer semestre de 1996, Buenos Aires.

-Mayo, Carlos, Vivir en la frontera. La casa, la dieta, la pulpería, la escuela (1770-1870), Biblos, Buenos Aires, 2000.

-Moreno, José Luis, "Sexo, matrimonio y familia: la ilegitimidad en la frontera pampeana del Río de la Plata, 1780-1850", Boletín del Instituto de Historia Argentina y Americana "Dr. Emilio Ravignani", núms. 16-17, segundo semestre de 1997 y primero de 1998, Buenos Aires.

-Nario, Hugo, Tata Dios. El Mesías de la última montonera, Plus Ultra, Buenos Aires, 1976.

-Ozslak, Óscar, La formación del Estado argentino. Orden, progreso y organización nacional, Universidad de Belgrano, Buenos Aires, 1982.

-Pratt, Mary Louise, Ojos imperiales. Literatura de viajes y transculturación, Ediciones de la Universidad Nacional de Quilmes, Bernal, 1997.

-Prieto, Adolfo, Los viajeros ingleses y la emergencia de la literatura argentina, 1820-1850, Editorial Sudamericana, Buenos Aires, 1996.

-Ratto, Silvia, "El negocio pacífico de los indios: la frontera bonaerense durante el gobierno de Rosas", Siglo XIX. Revista de Historia, 1994, México. 
"Indios amigos e indios aliados. Orígenes del negocio pacífico en la provincia de Buenos Aires (1829-1832)", Boletín del Instituto de Historia Argentina y Americana "Dr. Emilio Ravignani", núm. 5, 1994, Buenos Aires.

—, "¿Finanzas públicas o negocio privado? El sistema de racionamiento del negocio pacífico de indios en la época de Rosas" en Noemí Godlman y Ricardo Salvatore, Caudillismos rioplatenses. Nuevas miradas a un viejo problema, Eudeba, Buenos Aires, 1998.

-, "Cuando las fronteras se diluyen. Las formas de interrelación blanco-indias en el sur bonaerense" en Raúl Mandrini y Carlos Paz (comps.), Las fronteras bispanocriollas del mundo indigena latinoamericano en los siglos XVIII-XIX. Un estudio comparativo, Instituto de Estudios Histórico-Sociales-Universidad Nacional del Centro, Tandil, 2002 (en prensa).

-Rotker, Susana, Cautivos, olvidos y memoria en la Argentina, Ariel, Buenos Aires, 1999.

-Santos, Juan José, "Una revuelta rural en la frontera sur bonaerense: Tandil 1872", tesis de licenciatura, Facultad de Filosofia y Letras-Universidad de Buenos Aires, Buenos Aires, 1995.

-Socollow, Susan, "Los cautivos españoles en las sociedades indígenas: el contacto cultural a través de la frontera argentina", Anuario IEHS, Universidad Nacional del Centro, núm. 2, 1987. Tandil.

-Suárez Martínez, Manuel, Apuntes autobiográficos de 1845 a 1880 y notas biográficas de 1880 a 1917, Tandil, 1993.

-Torre, Juan Carlos, "Los crímenes de Tata Dios, el Mesías gaucho", Todo es Historia, núm. 4, 1967, Buenos Aires.

-Urdampilleta, Daniela, "La magna tarea de civilizar. Vecinos, comunidad y Estado en las escuelas de la campaña de Buenos Aires. El caso de Tandil, 1854-1875", tesis de maestría, Facultad de Ciencias Humanas-Universidad Nacional del Centro de la Provincia de Buenos Aires, Tandil, 2001.

- Walther, Juan Carlos, La conquista del desierto, Círculo Militar, Buenos Aires, 1964. 